OPEN ACCESS

Edited by:

Eva Ortega-Retuerta,

UMR 7621 Laboratoire

d'océanographie microbienne

(LOMIC), France

Reviewed by:

Frédéric André Corentin Le

Moigne,

UMR 7294 Institut Méditerranéen d'océanographie (MIO), France

Tiantian Tang,

Xiamen University, China

${ }^{*}$ Correspondence: Sang Heon Lee sanglee@pusan.ac.kr

Specialty section:

This article was submitted to

Aquatic Microbiology,

a section of the journal

Frontiers in Microbiology

Received: 30 October 2020 Accepted: 04 January 2021 Published: 21 January 2021

Citation:

Jo N, La HS, Kim J-H, Kim K, Kim BK, Kim MJ, Son W and Lee SH (2021) Different Biochemical Compositions of Particulate Organic Matter Driven by Major Phytoplankton Communities in the Northwestern

Ross Sea.

Front. Microbiol. 12:623600 doi: 10.3389/fmicb.2021.623600

\section{Different Biochemical Compositions of Particulate Organic Matter Driven by Major Phytoplankton Communities in the Northwestern Ross Sea}

\author{
Naeun Jo', Hyoung Sul La², Jeong-Hoon Kim³ ${ }^{3}$ Kwanwoo Kim¹, Bo Kyung Kim², \\ Myung Joon Kim ${ }^{1}$, Wuju Son ${ }^{2,4}$ and Sang Heon Lee ${ }^{1 *}$
}

\footnotetext{
' Department of Oceanography, Pusan National University, Busan, South Korea, ${ }^{2}$ Division of Ocean Sciences, Korea Polar Research Institute, Incheon, South Korea, ${ }^{3}$ Division of Life Sciences, Korea Polar Research Institute, Incheon, South Korea, ${ }^{4}$ Department of Polar Science, University of Science and Technology, Daejeon, South Korea
}

Marine particulate organic matter (POM) largely derived from phytoplankton is a primary food source for upper trophic consumers. Their biochemical compositions are important for heterotrophs. Especially, essential amino acids (EAAs) in phytoplankton are well known to have impacts on the survival and egg productions of herbivorous zooplankton. To estimate the nutritional quality of POM, the biochemical compositions [biomolecular and amino acid (AA) compositions] of POM were investigated in the northwestern Ross Sea during the late austral summer in 2018. Carbohydrates $(\mathrm{CHO})$ accounted for the highest portion among different biomolecules [CHO, proteins (PRT), and lipids (LIP)] of POM. However, the higher contribution of PRT and lower contribution of $\mathrm{CHO}$ were observed in the southern section of our study area compared to those in the northern section. The spatial distribution of total hydrolyzable AAs in POM was considerably influenced by phytoplankton biomass, which indicates that the main source of particulate AA was generated by phytoplankton. Our results showed that the relative contribution of EAA to the total AAs was strongly associated with EAA index (EAAl) for determining protein quality. This result indicates that higher EAA contribution in POM suggests a better protein quality in consistency with high EAAI values. In this study, variations in the biochemical compositions in POM were principally determined by two different bloom-forming taxa (diatoms and Phaeocystis antarctica). The southern region dominated majorly by diatoms was positively correlated with PRT, EAA, and EAAI indicating a good protein quality, while $P$. antarctica-abundant northern region with higher $\mathrm{CHO}$ contribution was negatively correlated with good protein quality factors. Climate-driven environmental changes could alter not only the phytoplankton community but also the physiological conditions of phytoplankton. Our findings could provide a better understanding for future climate-induced changes in the biochemical compositions of phytoplankton and consequently their potential impacts on higher trophic levels.

Keywords: phytoplankton, biomolecular composition, amino acid composition, food quality, Ross Sea 


\section{INTRODUCTION}

Marine particulate organic matter (POM) is derived from a variety of living and non-living sources, including detritus matter, bacterial cells, and phytoplankton (Volkman and Tanoue, 2002). Although the relative importance of these diverse sources cannot be clarified, phytoplankton is definitely the most important part of marine POM in surface waters (Riley, 1971; Kharbush et al., 2020). POM largely derived from phytoplankton plays a significant role in linking the primary producers to herbivores as a crucial food source (Dzierzbicka-Głowacka et al., 2010; Lowe et al., 2014; Andersson et al., 2017) and potential carbon export to the deep ocean (Ducklow et al., 2001; Basu and Mackey, 2018). Biochemical properties of POM, especially biomolecular and amino acid (AA) compositions, are useful indicators of nutritional quality for higher trophic consumers (Dell'Anno et al., 2000; Lee et al., 2004; Bhavya et al., 2019). The various biomolecular components, including carbohydrates $(\mathrm{CHO})$, proteins (PRT), and lipids (LIP), are generated through photosynthetic assimilation of dissolved inorganic carbon into organic compounds within phytoplankton (Fernández-Reiriz et al., 1989; Fichez, 1991). The relative contribution of the biomolecular compounds produced by phytoplankton is tightly linked to the prevailing environmental conditions (e.g., availability of nutrients and light), major phytoplankton groups, and the growth phase of phytoplankton (Ahn et al., 2019; Bhavya et al., 2019 and the references therein). Thus, the biomolecular composition of phytoplankton has also been considered a suitable indicator of the physiological responses of phytoplankton to the limitation of macro and micronutrients (i.e., bioavailable N, P, Si, and Fe) (Morris et al., 1974; Sterner and Elser, 2002; Saito et al., 2008; Moore et al., 2013) and light stress (Morris et al., 1974; Smith and Morris, 1980; Sunda and Huntaman, 1997; Klausmeier et al., 2008) which is consequently connected with their nutritional quality for higher trophic consumers (Bhavya et al., 2019).

On the one hand, it is well known that AAs are the building blocks of different biomolecules which are mainly peptides and PRT (Kolmakova and Kolmakov, 2019; Shields et al., 2019). Previous studies have shown that compositional changes in AAs are related to the degradation state of POM, phytoplankton community structure, and growth phase of phytoplankton (Hecky et al., 1973; Kolmakova and Kolmakov, 2019; Shields et al., 2019). Therefore, these compositional changes of AAs have widely been used to indicate the organic matter degradation (Cowie and Hedges, 1992; Mente et al., 2002; Becker and Richmond, 2004) and protein quality (Oser, 1959; Mente et al., 2002; Becker and Richmond, 2004). The degradation index (DI) based on the changes in the relative abundance of each AA to total AAs during organic matter diagenesis can be applied to estimate the degradation degree of POM in sediment as well as sinking particles (Dauwe and Middelburg, 1998; Dauwe et al., 1999; Le Moigne et al., 2017). Among different AAs, essential AAs (EAAs) cannot be synthesized de novo by most heterotrophic organisms and must therefore be fulfilled by prey to meet consumer's nutritional needs for their growth and reproduction (Muller-Navarra, 1995; Kleppel et al., 1998;
Kolmakova and Kolmakov, 2019). However, nutritional quality for higher trophic levels comprises not only the quantity of EAA but also balance in individual EAAs (Müller-Navarra, 2008). Hence, the EAA index (EAAI) allows us to evaluate the protein quality in terms of the AA composition of POM as consumers' diets.

The Ross Sea is one of the most productive regions in the Southern Ocean and thus supporting considerable standing stocks of apex predators such as penguins, seals, and whales (Nelson et al., 1996; Pinkerton et al., 2010). In 2016, this region was established as a massive Marine Protected Area (MPA) safeguarding 1.55 million $\mathrm{km}^{2}$ of ocean bordering Antarctica from ice edge to deep ocean by the Commission for the Conservation of Antarctic Marine Living Resources (CCAMLR). Of that, cape Hallett located at the northern Victoria Land is one of the specially protected areas and large populations of breeding penguins relevant to large aggregations of krill as their primary food source (Lyver et al., 2011). The marine top predators (e.g., penguins, seals, and whales) depend directly or indirectly on organic matter by photosynthetic microalgae since the quantity and quality of POM produced by phytoplankton have consequences for the entire marine ecosystem of the Ross Sea through bottom-up processes (Oksanen and Oksanen, 2000; Gruner et al., 2008). Indeed, the Ross Sea food webs are supported at their foundation by phytoplankton comprising of two key algal groups: diatoms and haptophytes, particularly Phaeocystis antatarctica (DiTullio and Smith, 1996; Alderkamp et al., 2012; Smith et al., 2014; Mangoni et al., 2017). The relative abundance of major two phytoplankton communities varies with spatial and temporal patterns in the Ross Sea and subsequently can have significant influences on the spatial and temporal diet variability of higher trophic levels (trophodynamics) (Young et al., 2015b; Mangoni et al., 2019). According to current climate trends, the Ross Sea is expected to experience extreme warming, decreased sea ice concentrations, and shallower mixed layers throughout the next century (Bracegirdle et al., 2008; Ainley et al., 2010; Bracegirdle and Stephenson, 2012). The changes in the predominant phytoplankton community and physiological status of phytoplankton caused by this predicted climate change (e.g., increase in sea surface temperatures, decreases in the mixed layer depths, sea ice concentrations, and macronutrient concentrations; Rickard and Behrens, 2016) can have profound implications on diet variability of higher trophic levels (Smith et al., 2003; Smetacek et al., 2004; Tang et al., 2008). Therefore, the aims of the paper were to (1) investigate biochemical compositions (biomolecular and AA compositions) of POM derived mainly phytoplankton and main factors in controlling the relative dominance of these biochemical compositions and (2) evaluate physiological conditions of phytoplankton and potential food quality as prey for consumers.

\section{MATERIALS AND METHODS}

\section{Study Sites and Sampling}

The field survey was performed closely to Cape Adare and Cape Hallett during the Ross Sea Marine Projected Area Expedition 
(ANA08C; from 25 February to 1 March 2018) in Antarctica on the IBR/V Araon (Figure 1). The vertical temperature and salinity profiles were collected using a conductivity-temperaturedepth (CTD) recorder (SeaBird Electronics Inc., SBE 911 plus). At all sampling stations, discrete water samples for biological and chemical analyses were obtained from three different light levels (100, 30, and $1 \%$ light penetration depths which were estimated from the Secchi depth) employing CTD/rosette sampler attached to 24-10 L Niskin bottles. The depth of the euphotic zone $\left(Z_{e u}\right)$ was defined as the depth at which $99 \%$ of the surface irradiance is attenuated (Kirk, 1985) and estimated using a Secchi disk. The mixed layer depth $\left(\mathrm{Z}_{\mathrm{m}}\right)$ was defined as the depth where a change of $0.01 \mathrm{~kg} \mathrm{~m}^{-3}$ in potential density $\left(\sigma_{\mathrm{t}}\right)$ from the stable surface layer value (Smith et al., 2000; Asper and Smith, 2019).

\section{Particulate Organic Carbon (POC), Nitrogen (PON), and Stable Carbon Isotopes $\left(\delta^{13} \mathrm{C}\right)$ Analyses of POM}

For the analyses of POC, PON, and $\delta^{13} \mathrm{C}, 0.3 \mathrm{~L}$ of sampled sample was filtered through Whatman $\mathrm{GF} / \mathrm{F}$ filter $(25 \mathrm{~mm}$, $0.7 \mu \mathrm{m}$ pore) and immediately stored at $-80^{\circ} \mathrm{C}$. The filtered samples were acidified over fuming $\mathrm{HCl}$ to eliminate inorganic carbon before further analysis. Then, the filters were analyzed for carbon and nitrogen contents and isotope ratios using a Finnigan Delta + XL mass spectrometer at the stable isotope laboratory of the University of Alaska Fairbanks, United States.

\section{Major Inorganic Nutrients, Chlorophyll a, and Other Phytoplankton Pigments Analyses}

Samples for the determination of dissolved inorganic nutrients (phosphate, nitrate + nitrite, ammonium, and silicate) were collected directly from the Niskin rosette into $50 \mathrm{~mL}$ conical tubes and immediately stored at $4^{\circ} \mathrm{C}$ until analysis within
$24 \mathrm{~h}$. Nutrient concentrations were measured on board with a QuAAtro Continuous Segmented Flow Analyzer (Seal Analytical, Norderstedt, Germany) using standard colorimetric methods according to the "QuAAtro Applications."

Water samples $(0.3 \mathrm{~L})$ were filtered through $25 \mathrm{~mm} \mathrm{GF} / \mathrm{F}$ filter papers (Whatman, $0.7 \mu \mathrm{m}$ pore) to measure the total chlorophyll a (chl- $a$ ) concentration. Sequential filtrations were performed to determine each size-fractionated chl- $a$ concentration $(>20,5-20$, and $<5 \mu \mathrm{m}$ ). First, $0.5 \mathrm{~L}$ of seawater was filtered through the Polycarbonate Track Etched (PCTE) membrane $20 \mu \mathrm{m}$ filter (GVS, $47 \mathrm{~mm}$ ). Then, the filtrate was passed through the PCTE membrane $5 \mu \mathrm{m}$ filter (Whatman, $47 \mathrm{~mm}$ ) and $47 \mathrm{~mm} \mathrm{GF} / \mathrm{F}$ filters (Whatman, $0.7 \mu \mathrm{m}$ pore) in sequence. The chl- $a$ pigment was extracted by submerging filtered samples in $90 \%$ acetone for $24 \mathrm{~h}$ in dark and cold conditions (Parsons et al., 1984). The chl$a$ fluorescence was measured onboard using the pre-calibrated Trilogy fluorometer (Turner Designs, United States).

Phytoplankton pigment analysis using a high-performance liquid chromatography (HPLC) system can be used to quantify concentrations of each pigment that were determined by measuring the integrated peak area based on the method of Zapata et al. (2000). The pigments on the filtered samples (1 or $2 \mathrm{~L}$ of seawater) were extracted in $5 \mathrm{~mL}$ of $100 \%$ acetone with canthaxanthin (internal standard) for $24 \mathrm{~h}$ in dark at $4^{\circ} \mathrm{C}$. The extract was filtered through a $0.2 \mu \mathrm{m}$ Advantec syringe filter. HPLC measurements were performed on an Agilent 1200 HPLC system (Agilent infinite 1260, Agilent, United States) and the separating column was used Zobrax Eclipse XDB C8 column $(250 \times 4.6 \mathrm{~mm}, 5 \mu \mathrm{m}$, Agilent Technologies $)$. The same analysis procedures of Kang et al. (2018) were performed for quantifying of pigment concentrations. As suggested by Mackey et al. (1996), the contribution of various phytoplankton classes could be estimated by the ratio of each diagnostic pigment to total chl- $a$ using the CHEMTAX program. The initial pigment ratio to chl- $a$ for each mark pigment used in the CHEMTAX

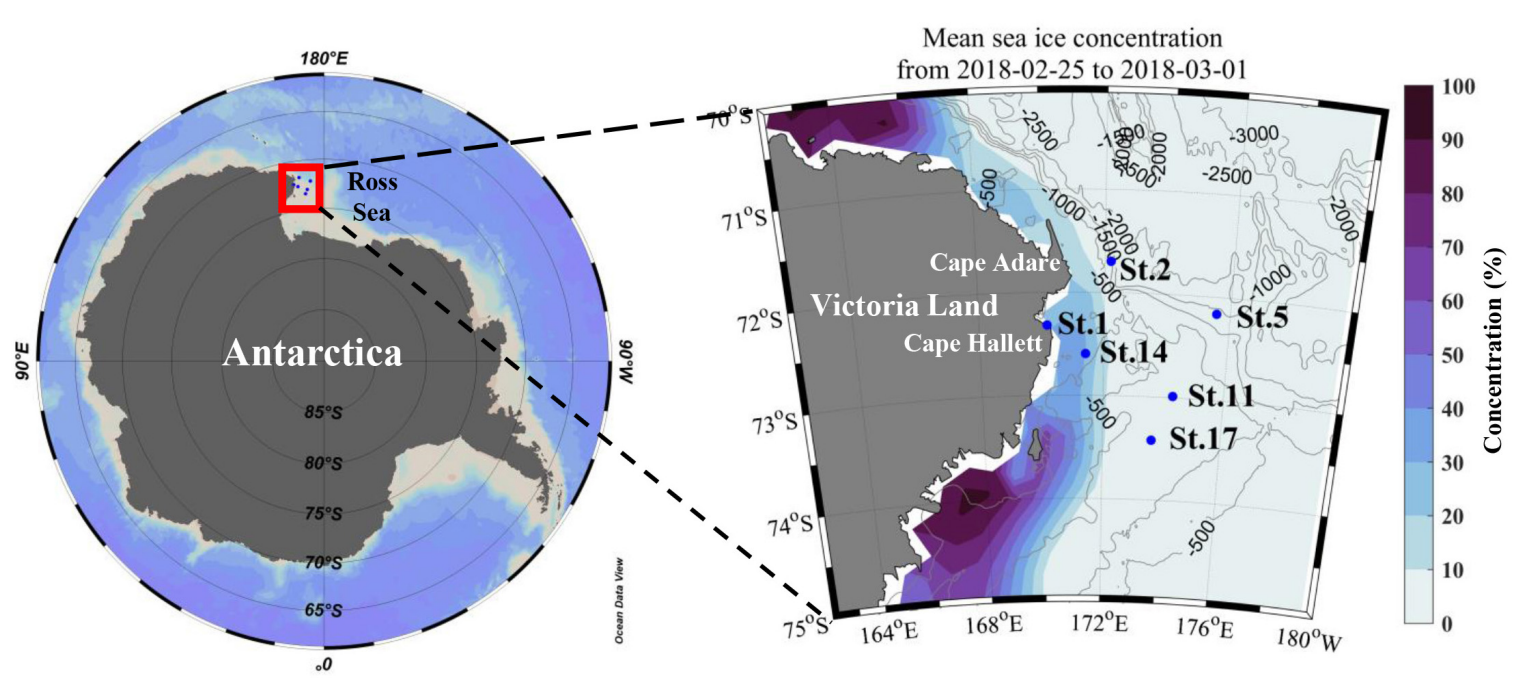

FIGURE 1 | Map of the study area and sampling stations (with depth contours in meters). Mean sea ice concentration (\%) data during the sampling period from Nimbus-7 SMMR and DMSP SSM/I-SSMIS Passive Microwave data provided by National Snow and Ice Data Center. 
program was modified by Mackey et al. (1996); Wright et al. (1996), and DiTullio et al. (2011).

\section{Biomolecular Composition of Phytoplankton}

Water samples were obtained from three light depths (100, 30, and $1 \%$ ) for biomolecular compositions (CHO, PRT, and LIP) of phytoplankton and filtered through a $47 \mathrm{~mm}$ GF/F filter. The filters were stored at $-80^{\circ} \mathrm{C}$ for spectrometric analysis using a UV-visible spectrometer (Hitachi UH-5300, Japan) to measure each biomolecular concentration. $\mathrm{CHO}$ concentration was determined using the phenol-sulfuric method according to Dubois et al. (1956). After $1 \mathrm{~mL}$ of deionized water was added to the polypropylene tube containing the filtered sample, samples were ultrasonicated for $20 \mathrm{~min}$ for $\mathrm{CHO}$ extraction. $1 \mathrm{~mL}$ of $5 \%$ phenol reagent was additionally added, and the extracted samples were kept at room temperature for $40 \mathrm{~min}$. The $\mathrm{CHO}$ after reaction with concentrated sulfuric acid were quantified by measuring the absorbance at $490 \mathrm{~mm}$ and then calculated from the calibration glucose standard ( $1 \mathrm{mg} \mathrm{mL}^{-1}$, SIGMA) curve. To measure PRT concentration based on Lowry et al. (1951), $1 \mathrm{~mL}$ of deionized water and $5 \mathrm{~mL}$ of alkaline copper solution (a mixture of $2 \% \mathrm{Na}_{2} \mathrm{CO}_{3}$ in $0.1 \mathrm{~N} \mathrm{NaOH}$ with $0.5 \% \mathrm{CuSO}_{4} \cdot 5 \mathrm{H}_{2} \mathrm{O}$ in $1 \%$ sodium or potassium tartrate; $50: 1, \mathrm{v}: \mathrm{v})$ were added into vials with the filtered samples for PRT extraction. After $20 \mathrm{~min}$ of ultrasonication, $0.5 \mathrm{~mL}$ of diluted Folin-Ciocalteu phenol reagent $(1: 1, \mathrm{v}: \mathrm{v})$ was added into sample vials for the colorimetric reaction. The absolute concentration of PRT was calculated from the absorbance at $750 \mathrm{~nm}$ comparing with a protein standard solution ( $2 \mathrm{mg} \mathrm{mL}^{-1}$, SIGMA). The total LIP was extracted by chloroform and methanol $(1: 2, \mathrm{v}: \mathrm{v})$ according to the modified method of Bligh and Dyer (1959) and Marsh and Weinstein (1966). The absorbance at $360 \mathrm{~nm}$ was expressed as tripalmitin equivalents. More detailed methods are explained in Bhavya et al. (2019).

\section{Amino Acid Composition Analysis}

Samples for the analysis of total particulate hydrolyzable AAs (PAAs) were collected from three light depths (100, 30, and $1 \%)$ at six stations. Water samples (1 L) from each station were passed through $47 \mathrm{~mm} \mathrm{GF} / \mathrm{F}$ filters (Whatman, $0.7 \mu \mathrm{m}$ pore) and then frozen at $-80^{\circ} \mathrm{C}$ for later analysis. Acid hydrolysis was performed using the modified methods of Lobbes et al. (1999) and Bartolomeo and Maisano (2006). A filtered paper is transferred into the $5 \mathrm{~mL}$ reaction vial containing $2 \mathrm{~mL}$ $\mathrm{HCl}(6 \mathrm{M})$ and $10 \mu \mathrm{L}$ ascorbic acid $(11 \mathrm{mM})$. The vials were capped tightly after flushing with $\mathrm{N}_{2}$ gas and then moved into a pre-heated heating block at $110^{\circ} \mathrm{C}$ for $24 \mathrm{~h}$. After acidic hydrolysis, hydrolysates were cooled at room temperature and filtered through $0.2 \mu \mathrm{m}$ PTFE syringe filters (Advantec, Tokyo, Japan). Each remaining liquid was evaporated to dryness using a nitrogen evaporator at $60^{\circ} \mathrm{C}$. The dried residues were reconstituted with $200 \mu \mathrm{L}$ of $0.1 \mathrm{~N} \mathrm{HCl}$ and transferred into glass vials for analysis. Samples were analyzed using HPLC (Agilent 1260 Infinity, Germany) equipped with an autosampler, a Zorbax-Eclipse AAA column $(4.6 \times 250 \mathrm{~mm}$,
$5 \mu \mathrm{m}$ ), and UV/VIS detector (338 and $262 \mathrm{~nm}$ ). In the pre-column method, the samples and AA standard solutions were automatically derivatized with ortho-phthalaldehyde (OPA) and 9-fluorenylmethyl chloroformate (FMOC) by programming autosampler according to Agilent Application note (Henderson et al., 2000). The column temperature was maintained at $40^{\circ} \mathrm{C}$ with a flow rate of $1.5 \mathrm{~mL} / \mathrm{min}$. The mobile phase A contained $40 \mathrm{mM}$ sodium phosphate (di-basic) with $0.1 \%$ phosphoric acid and mobile phase B was acetonitrile/methanol/deionized water (45:45:10, v:v:v). AA standard mixture with 21 LAAs and L-norvaline (surrogate standard) was prepared for AA identification and quantification. AA standard solutions contained 22 L-AAs: Aspartic acid (ASP), Glutamic acid (GLU), Asparagine (ASN), Serine (SER), Glutamine (GLN), Histidine (HIS), Glycine (GLY), Threonine (THR), Arginine (ARG), Alanine (ALA), Tyrosine (TYR), Cystine (CY2), Valine (VAL), Methionine (MET), Tryptophan (TRP), Phenylalanine (PHE), Isoleucine (ILE), Leucine (LEU), Lysine (LYS), Hydroxyproline (HYP), Proline (PRO) and Norvaline (NVA). Hydroxyproline (HYP), and proline (PRO) could not be quantified because of their low responses and high detection limits in our HPLC. A representative chromatogram for the mixed standard is shown in Supplementary Figure S1. Each linear relationship for the four-point calibration curve of individual AAs was obtained with a correlation coefficient being above 0.999 . The relative standard deviations of peak areas for each AA in each point ranged from 1.6 to $9.5 \%(n=3)$ for measurement precisions. Before injecting, $20 \mu \mathrm{L}$ of norvaline as a surrogate standard has added a sample of each vial and each sample was injected twice for HPLC analysis. Peak areas of AA measured that the average value of three blanks was subtracted from each sample analyzed. Then, individual AA concentrations in injected samples were calculated using the slope of the calibration curve of each AA and the known concentration of Norvaline. Glutamine (GLN) and asparagine (ASN) were quantified as glutamic acid (GLU) and aspartic acid (ASP) because glutamine (GLN) and asparagine (ASN) react into glutamic acid (GLU) and aspartic acid (ASP) during hydrolysis, respectively. Moreover, tryptophan (TRP) and cystine (CY2) are omitted from our AA results since they are fully or partially destroyed during acid hydrolysis. Therefore, the concentration of each remaining AA was expressed as a mole percentage (mol\%) of the total AA.

\section{Amino Acid Index Calculations}

The quantitative DI for POM was calculated using mol\% AA composition and the factor coefficient of Dauwe et al. (1999). According to Dauwe et al. (1999), this index could reflect the reactivity of POM as degradation proceeds. DI was estimated using this equation derived by Dauwe et al. (1999).

$$
D I=\sum_{i}\left[\frac{\text { var }_{i}-\text { AVGvar }_{i}}{S T D \text { var }_{i}}\right] \times f a c \cdot \operatorname{coef}_{i}
$$

In this equation, $\operatorname{var}_{i}$ is the mol\% of the individual AA, $A_{\text {AVvar }}$ and STDvar $i$ are the mean and standard deviation of the $\mathrm{AA}$ mol\% in a given dataset, and fac. coef $_{i}$ is the factor coefficient in Dauwe et al. (1999). 
Individual AA of each sample is divided into EAA and non-EAA (NEAA): nine essential (histidine, threonine, arginine, valine, methionine, phenylalanine, isoleucine, leucine, and lysine) and six non-essential (aspartic acid, glutamic acid, serine, glycine, alanine, and proline). The EAAI is a common index for estimating the quality of phytoplankton as a diet for higher trophic levels such as zooplankton (Oser, 1959; Mente et al., 2002; Becker and Richmond, 2004). The EAAI is defined as a ratio of EAA in prey to corresponding EAA in reference egg protein (Oser, 1959). However, the mean fraction of EAA in the zooplankton community in this study (unpublished data) was used as the reference AA since efficient food has a similar AA profile to that of the consumer (Guisande et al., 2002). The modified EAAI of POM was determined from this formula:

$$
E A A I=\sqrt[n]{\frac{a a_{1}}{A A_{1}} \times \frac{a a_{2}}{A A_{2}} \times \frac{a a_{3}}{A A_{3}} \times \frac{a a_{4}}{A A_{4}} \times \cdots \times \frac{a a_{n}}{A A_{n}}}
$$

where $a a_{1}, \ldots, a a_{n}$ are the ratio of each EAA to total EAA in POM and $A A_{1}, \ldots, A A_{n}$ are the average ratio of each EAA to total EAA in zooplankton communities in this study (unpublished data). To calculate EAAI, the values of $a a_{1} / A A_{1}, \ldots, a a_{n} / A A_{n}$ were constrained between 0.01 minimally and 1 maximally (Hayashi et al., 1986).

\section{Statistical Analysis}

Significant differences of biochemical properties (concentrations of biomolecules and biomolecular composition) between northern and southern stations were tested using the Student's $t$-test. The results of statistical analyses were assumed to be significant at $p$-values $<0.05$. All correlation analyses were performed in this study using Pearson's correlation coefficients. Statistical analyses were performed using Statistical Package for the Social Sciences (SPSS ver.12.0). For the multivariate analysis of the analyzed and investigated parameters, we carried out the principal component analysis (PCA) with the rotation method of Varimax with Kaiser normalization using the XLSTAT software (Addinsoft, Boston, MA, United States). Further, to calculate the dissimilarity between samples, agglomerative hierarchical clustering (AHC) analysis with Euclidean distance dissimilarity and Ward's method was conducted using the XLSTAT software (Addinsoft, Boston, MA, United States).

\section{RESULTS}

\section{Hydrographical and Chemical Properties}

The vertical profiles of potential temperature and salinity within the upper $100 \mathrm{~m}$ ranged from -1.82 to $-0.52^{\circ} \mathrm{C}$ and from 33.96 to 34.58 , respectively (Figure 2 ). The lowest potential temperature and salinity were measured at station (St.) 1 , whereas other stations never reached freezing temperature and had relatively higher salinities. The higher salinity values over 34.40 with depth showed at Sts. 14 and 17 which also had higher temperature values. The $Z_{e u}$ and $Z_{m}$ were $30-43$ and $20-117 \mathrm{~m}$, respectively (Table $\mathbf{1}$ ). The $Z_{e u}$ at most stations was shallower than $Z_{m}$ except for Sts. 1 and 11 .

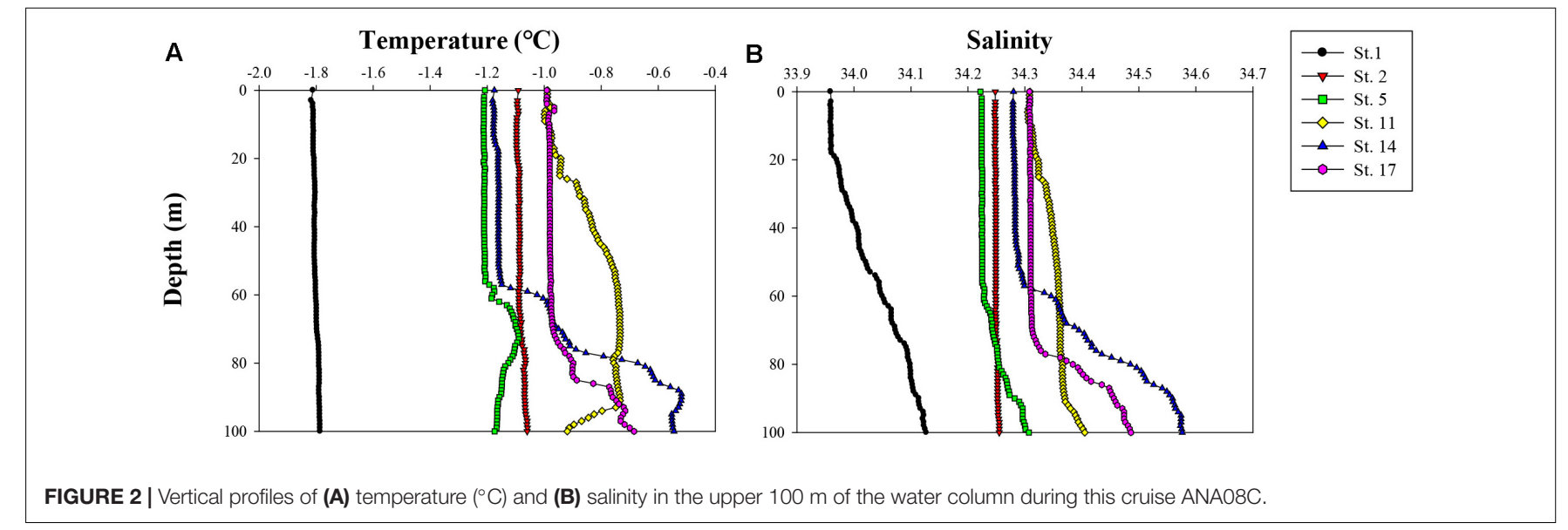

TABLE 1 | Description of sampling stations and associated environmental variables during ANA08C cruise.

\begin{tabular}{|c|c|c|c|c|c|c|c|c|}
\hline Station & Latitude ( $\left.{ }^{\circ} \mathbf{N}\right)$ & Logitude ( $\left.{ }^{\circ} \mathrm{E}\right)$ & Date (mm/dd/yy) & $\mathbf{T}_{e u}$ & $\mathrm{~S}_{e u}$ & Bottom depth (m) & $\mathrm{Z}_{e u}(\mathrm{~m})$ & $\mathrm{Z}_{m}(\mathrm{~m})$ \\
\hline 1 & -72.318 & 170.177 & $25 / 02 / 18$ & -1.8 & 34.0 & 165 & 43 & 21 \\
\hline 2 & -71.698 & 172.186 & $26 / 02 / 18$ & -1.1 & 34.2 & 1043 & 35 & 117 \\
\hline 5 & -72.163 & 175.566 & $27 / 02 / 18$ & -1.2 & 34.2 & 1342 & 38 & 65 \\
\hline 11 & -72.987 & 174.315 & 28/02/18 & -1.0 & 34.3 & 345 & 30 & 20 \\
\hline 14 & -72.596 & 171.413 & $28 / 02 / 18$ & -1.2 & 34.3 & 387 & 41 & 53 \\
\hline 17 & -73.421 & 173.662 & 01/03/18 & -1.0 & 34.3 & 287 & 30 & 75 \\
\hline
\end{tabular}

$T_{\text {eu }}$ and $S_{\text {eu }}$ : water temperature and salinity averaged from surface to the euphotic zone depth $\left(Z_{\text {eu }}\right)$.

$Z_{m}$ : mixed layer depth. 
Figure 3 shows vertical distributions of dissolved inorganic nutrients (phosphate, nitrate + nitrite, ammonium, and silicate) from the surface to $100 \mathrm{~m}$ depth. The concentrations of dissolved inorganic nutrients except for ammonium mostly increased with depth from the surface to $100 \mathrm{~m}$. At Sts. 14 and 17 , the concentrations of phosphate, nitrate + nitrite, and silicate increased sharply below the euphotic layers compared with those at other stations. In the upper $100 \mathrm{~m}$, the concentrations of phosphate, nitrate + nitrite, and silicate were 1.89-2.38, 19.11-22.66, and 60.74-81.53 $\mu \mathrm{M}$, respectively. Dissolved inorganic ammonium had low concentrations, ranging from 0 to $1.49 \mu \mathrm{M}$, and did not show a clear spatial pattern.

\section{Particulate Organic Carbon (POC), Nitrogen (PON), and Stable Carbon Isotopes $\left(\delta^{13} \mathrm{C}\right)$ of POM}

The averaged concentrations of POC, $\mathrm{PON}$, and $\mathrm{C} / \mathrm{N}$ ratio within the euphotic zone and $\delta^{13} \mathrm{C}$ values of surface POM are summarized in Table 2. The POC and PON concentrations were 108.0-194.5 and 11.1-27.5 $\mu \mathrm{g} \mathrm{L}^{-1}$, respectively. The lowest mean values of the euphotic depth-averaged POC and PON were observed at St. 2 while the highest values were found at St. 17 (Table 2). The $\mathrm{C} / \mathrm{N}$ ratios were in a range of 7.7-11.4 and the average $\mathrm{C} / \mathrm{N}$ ratio value was highest at St. $1(10.8 \pm 0.6)$ and lowest at St. $17(8.0 \pm 0.3)$ (Table 2). The $\delta^{13} \mathrm{C}$ values of surface POM ranged from -25.1 (St. 1) to $-29.2 \%$ (St. 17) (Table 2).

\section{Phytoplankton Biomass and Community Structure}

The vertical patterns of the total chl- $a$ concentrations between the surface and 1\% light depth are shown in Table 3 and were almost uniform throughout the euphotic zone at each station (Table 3). Depth-integrated total chl-a concentrations throughout the euphotic zone (from the surface to depth of $Z_{e u}$ ) ranged between 13.1 and $42.6 \mathrm{mg}$ chl- $a \mathrm{~m}^{-2}$, with a mean value of $24.7 \mathrm{mg}$ chl- $a \mathrm{~m}^{-2}$ (SD = $\pm 11.1 \mathrm{mg}$ chl- $\left.a \mathrm{~m}^{-2}\right)$. The lowest integrated chl- $a$ values were observed at the northernmost Sts. 2 and 5, while the highest value was found at the southernmost and near the offshore station (St. 17). We found a distinct difference in chl-a contributions of different size classes ( $>20,5-20$, and 0.7-5 $\mu \mathrm{m})$ to the total chl- $a$ concentration among the stations (Table 3). The large-sized phytoplankton $(>20 \mu \mathrm{m})$ contributed most to the total phytoplankton biomass in the southern part of the study area (Sts. 11, 14, and 17), whereas relatively smaller cells $(0.7-5$ and 5-20 $\mu \mathrm{m})$ were dominating in the northern part (Sts. 1, 2, and 5). The overall contributions of large $(>20 \mu \mathrm{m})$, middle $(5-20 \mu \mathrm{m})$, and small-sized $(0.7-5 \mu \mathrm{m})$ phytoplankton to the total chl- $a$ concentrations were $14.7-82.8,11.1-47.4$, and $5.6-47.1 \%$, respectively. Moreover, the contribution of largesized fraction $(>20 \mu \mathrm{m})$ showed a statistically significant positive correlation with integrated total chl- $a$ concentration $(r=0.888$, $p<0.05)$, whereas a significant negative correlation was found between small size-class $(0.7-5 \mu \mathrm{m})$ and integrated total chl- $a$ value $(r=-0.910, p<0.05)$ in our study area.

Concerning the relative contributions of individual phytoplankton groups based on CHEMTAX analysis

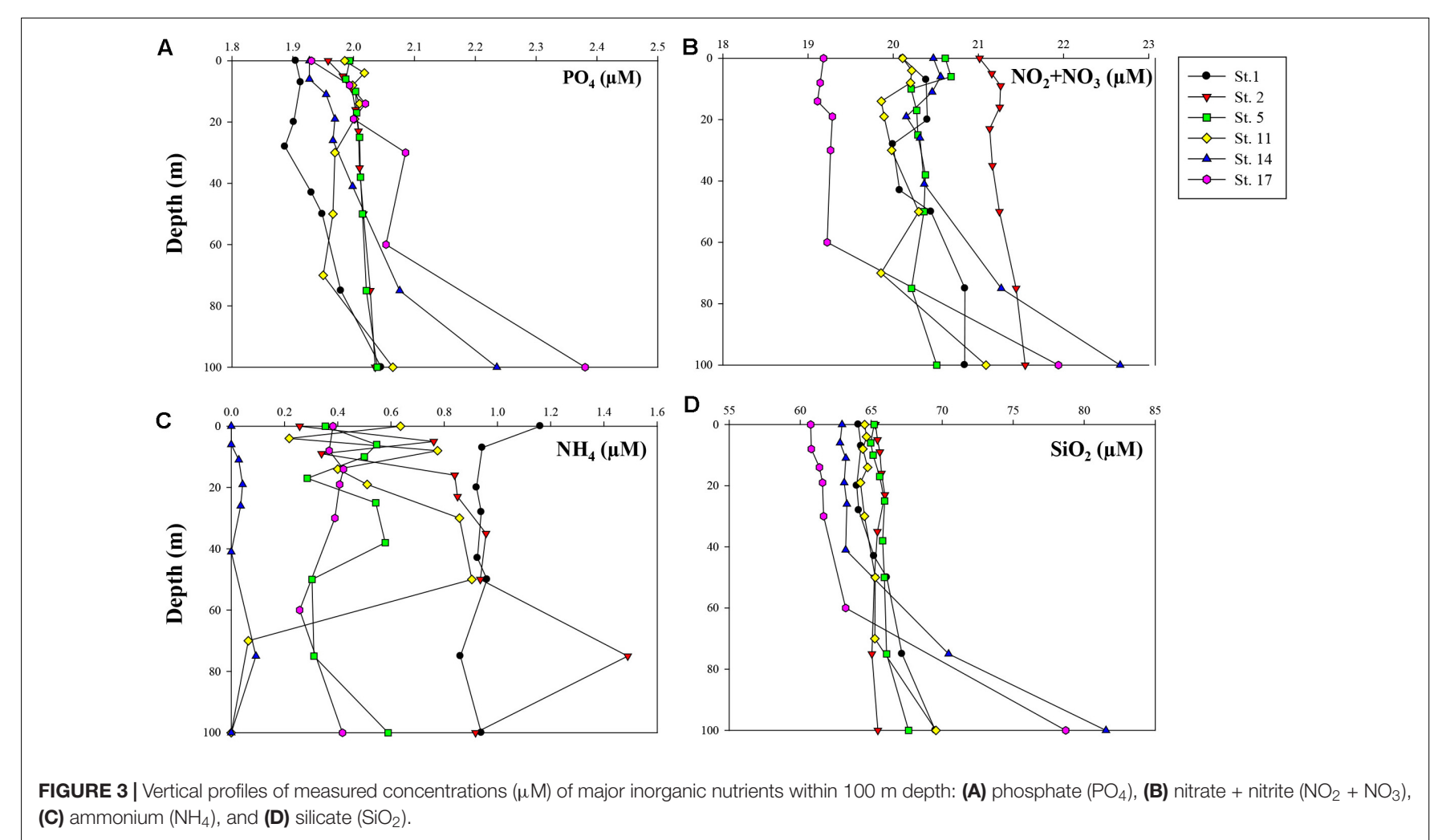


TABLE 2 | The concentrations of POC and PON, and $813 \mathrm{C}(\%)$ of particulate organic matter (POM) in the northwestern Ross Sea.

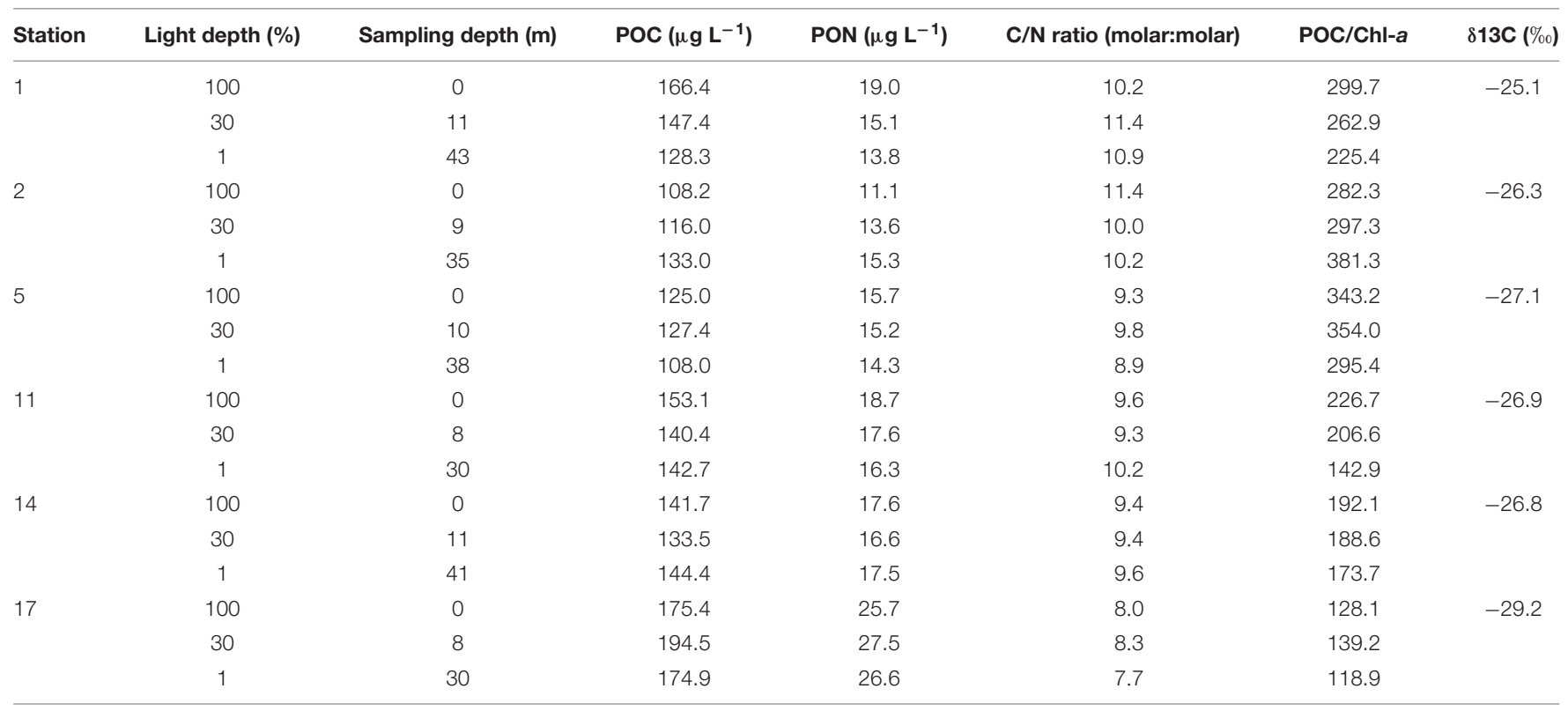

TABLE 3 | Total and euphotic-depth integrated chl-a concentrations (from the surface to 1\% light depth) and compositions of different size-fractionated chl-a and phytoplankton communities.

\begin{tabular}{|c|c|c|c|c|c|c|c|c|c|c|}
\hline \multirow[t]{2}{*}{ Station } & \multirow[t]{2}{*}{ Light depth (\%) } & \multicolumn{2}{|c|}{ Total } & \multicolumn{3}{|c|}{ Size-fractionated (\%) } & \multicolumn{4}{|c|}{ Phytoplankton community composition (\%) } \\
\hline & & Chl-a $\left(\mu \mathrm{g} \mathrm{L}^{-1}\right)$ & $\begin{array}{l}\text { Integrated (mg } \\
\text { chl-a } \mathbf{m}^{-2} \text { ) }\end{array}$ & $>20 \mu \mathrm{m}$ & $5-20 \mu \mathrm{m}$ & $0.7-5 \mu \mathrm{m}$ & Diatoms & Haptophytes & Dinoflagellates & Others \\
\hline \multirow[t]{3}{*}{1} & 100 & 0.6 & 24.2 & 16.6 & 40.0 & 43.4 & 74.3 & 25.2 & 0.3 & 0.2 \\
\hline & 30 & 0.6 & & 29.0 & 43.1 & 27.9 & 76.4 & 23.1 & 0.3 & 0.2 \\
\hline & 1 & 0.6 & & 25.4 & 47.4 & 27.2 & 77.5 & 22.0 & 0.4 & 0.0 \\
\hline \multirow[t]{3}{*}{2} & 100 & 0.4 & 13.1 & 17.1 & 39.2 & 43.7 & 37.1 & 62.4 & 0.3 & 0.2 \\
\hline & 30 & 0.4 & & 16.2 & 36.7 & 47.1 & 25.3 & 74.4 & 0.4 & 0.0 \\
\hline & 1 & 0.3 & & 14.7 & 42.8 & 42.5 & 33.9 & 65.7 & 0.4 & 0.0 \\
\hline \multirow[t]{3}{*}{5} & 100 & 0.4 & 13.8 & 15.3 & 43.5 & 41.2 & 48.7 & 48.1 & 0.0 & 3.2 \\
\hline & 30 & 0.4 & & 16.5 & 43.2 & 40.3 & 54.6 & 42.0 & 0.0 & 3.4 \\
\hline & 1 & 0.4 & & 18.8 & 42.4 & 38.8 & 55.2 & 41.0 & 0.0 & 3.8 \\
\hline \multirow[t]{3}{*}{11} & 100 & 0.7 & 23.9 & 59.4 & 22.0 & 18.7 & 72.2 & 20.8 & 0.6 & 6.4 \\
\hline & 30 & 0.7 & & 60.7 & 22.3 & 17.0 & 79.6 & 16.1 & 0.5 & 3.8 \\
\hline & 1 & 1.0 & & 71.5 & 18.6 & 9.9 & 91.4 & 5.6 & 0.6 & 2.5 \\
\hline \multirow[t]{3}{*}{14} & 100 & 0.7 & 30.7 & 59.2 & 25.9 & 14.9 & 93.1 & 0.2 & 0.6 & 6.1 \\
\hline & 30 & 0.7 & & 64.4 & 21.4 & 14.3 & 79.1 & 18.9 & 0.6 & 1.4 \\
\hline & 1 & 0.8 & & 50.4 & 35.0 & 14.6 & 74.6 & 22.3 & 0.9 & 2.2 \\
\hline \multirow[t]{3}{*}{17} & 100 & 1.4 & 42.6 & 82.5 & 11.9 & 5.6 & 95.5 & 0.1 & 0.3 & 4.1 \\
\hline & 30 & 1.4 & & 82.5 & 11.1 & 6.3 & 95.1 & 0.0 & 0.6 & 4.3 \\
\hline & 1 & 1.5 & & 82.8 & 11.3 & 5.9 & 95.8 & 0.1 & 0.3 & 3.7 \\
\hline
\end{tabular}

(Mackey et al., 1996; Wright et al., 1996; DiTullio et al., 2011), the combined contributions of diatoms and haptophytes (hereinafter Phaeocystis antarctica) contributed up to $99.6 \%$ of the total phytoplankton biomass during this study (Table 3). The phytoplankton community composition exhibited varying vertical distribution patterns and did not show clear differences between the three light depths (Table 3). Although most of the stations were diatoms-dominated with relatively low contributions of $P$. antarctica, $P$. antarctica presented markedly higher contributions at Sts. 2 and 5 (mean $\pm \mathrm{SD}=67.5 \pm 6.2$ and $43.7 \pm 3.8 \%$, respectively) (Table 3 ). Since two major groups, diatoms and $P$. antarctica, were distinctly observed during our study period, they could be related with different cell sizes based on our size-fractionated chl- $a$ results. The size-fractionated chl- $a$ and pigment analyses revealed that the larger phytoplankton assemblage $(>5 \mu \mathrm{m})$ was dominated by diatoms $(r=0.917$, $p<0.05)$. In comparison, the greater fraction of chl- $a$ contained in small cells $(<5 \mu \mathrm{m})$ accounted for mainly $P$. antarctica 
$(r=0.929, p<0.01)$, presumably indicative for solitary cells of $P$. antarctica ( $\sim 4 \mu \mathrm{m}$ in size; Schoemann et al., 2005).

\section{Biomolecular Composition of POM}

The concentrations and relative composition of $\mathrm{CHO}$, PRT, LIP, and food material (FM; the sum of CHO, PRT, and LIP; Danovaro et al., 2000) concentrations are presented in Table 4. The differences in concentrations of each biochemical pool (CHO, PRT, and LIP) and FM at these different three-light depths did not show a clear pattern. The absolute concentrations of each biomolecule (CHO, PRT, and LIP) and FM were 67.4-161.6, 7.9-75.6, 43.8-118.0, and 163.4-278.4 $\mu \mathrm{g} \mathrm{L}^{-1}$, respectively (Table 4). There was no clear difference in the $\mathrm{CHO}$ concentrations among the stations. In contrast, the PRT, LIP, and FM contents exhibited higher values in the southern part compared to those in the northern part $(t$-test, $p<0.05)$, in particular for PRT and FM contents $(t$-test, $p<0.001)$. Based on Pearson's correlation analysis, the PRT, LIP, and FM contents were found to have a positive relationship with chl- $a$ concentration as an indicator of phytoplankton biomass (PRT vs. Chl- $a$ : $r=0.915, p<0.01$; LIP vs. Chl- $a: r=0.787$, $p<0.01$; FM vs. Chl- $a: r=0.806, p<0.01$ ). Regarding the relative percentages of biomolecular components at each station, $\mathrm{CHO}$ made up the largest portion with a mean percentage of $54.0 \pm 10.2 \%$, increasing to $\sim 66.7 \%$ at the $1 \%$ light depth, followed by LIP (mean \pm SD $=29.9 \pm 5.4 \%$ ) and PRT (mean $\pm \mathrm{SD}=16.1 \pm 6.8 \%$ ) (Table 4). Although the biomolecular compositions of phytoplankton varied without vertical trends, the $\mathrm{CHO}$ and PRT compositions exhibited spatial variability between the northern and southern parts (Table 4). More

TABLE 4 | Concentrations of each biomolecular component (CHO, PRT, and LIP) and food materials (FMs) and percentages of the biomolecular composition of POM at each station in the northwestern Ross Sea.

\begin{tabular}{|c|c|c|c|c|c|c|c|c|}
\hline \multirow[t]{2}{*}{ Station } & \multirow{2}{*}{$\begin{array}{c}\text { Light } \\
\text { depth (\%) }\end{array}$} & \multicolumn{4}{|c|}{ Concentration $\left(\mu \mathrm{g} \mathrm{L}^{-1}\right)$} & \multicolumn{3}{|c|}{ Composition (\%) } \\
\hline & & Сно & PRT & LIP & $\mathbf{F M}$ & $\mathrm{CHO}$ & PRT & LIP \\
\hline \multirow[t]{3}{*}{1} & 100 & 122.8 & 23.1 & 53.3 & 199.2 & 61.6 & 11.6 & 26.8 \\
\hline & 30 & 118.4 & 7.9 & 58.4 & 184.7 & 64.1 & 4.3 & 31.6 \\
\hline & 1 & 121.3 & 11.4 & 49.3 & 182.0 & 66.7 & 6.2 & 27.1 \\
\hline \multirow[t]{3}{*}{2} & 100 & 122.8 & 22.4 & 50.7 & 195.9 & 62.7 & 11.4 & 25.9 \\
\hline & 30 & 97.8 & 23.1 & 43.8 & 164.7 & 59.4 & 14.0 & 26.6 \\
\hline & 1 & 114.8 & 16.9 & 47.4 & 179.1 & 64.1 & 9.4 & 26.5 \\
\hline \multirow[t]{3}{*}{5} & 100 & 96.8 & 21.7 & 44.9 & 163.4 & 59.2 & 13.3 & 27.5 \\
\hline & 30 & 102.4 & 22.4 & 70.5 & 195.3 & 52.4 & 11.5 & 36.1 \\
\hline & 1 & 84.4 & 23.1 & 58.4 & 166.0 & 50.9 & 13.9 & 35.2 \\
\hline \multirow[t]{3}{*}{11} & 100 & 125.7 & 42.5 & 54.4 & 222.5 & 56.5 & 19.1 & 24.4 \\
\hline & 30 & 161.6 & 36.9 & 62.1 & 260.6 & 62.0 & 14.2 & 23.8 \\
\hline & 1 & 97.1 & 42.5 & 64.3 & 203.8 & 47.6 & 20.8 & 31.5 \\
\hline \multirow[t]{3}{*}{14} & 100 & 86.9 & 37.6 & 62.8 & 187.3 & 46.4 & 20.1 & 33.5 \\
\hline & 30 & 109.4 & 43.1 & 56.9 & 209.5 & 52.2 & 20.6 & 27.2 \\
\hline & 1 & 121.3 & 41.8 & 61.0 & 224.1 & 54.1 & 18.6 & 27.2 \\
\hline \multirow[t]{3}{*}{17} & 100 & 100.5 & 61.1 & 73.8 & 235.3 & 42.7 & 26.0 & 31.3 \\
\hline & 30 & 67.4 & 69.4 & 118.0 & 254.9 & 26.5 & 27.2 & 46.3 \\
\hline & 1 & 118.4 & 75.6 & 84.4 & 278.4 & 42.5 & 27.2 & 30.3 \\
\hline
\end{tabular}

specifically, CHO compositions in the northern part (Sts. 1, 2, and 5) were higher than those in the southern part (Sts. 11, 14 , and 17) ( $t$-test, $p<0.01)$. In comparison, PRT composition in the euphotic layer of the southern part has much higher values compared to those measured in the northern part ( $t$-test, $p<0.001)$. Meanwhile, we found that the proportion of $\mathrm{CHO}$ positively correlated with $P$. antactica composition $(r=0.609$, $p<0.01$ ) while the proportion of PRT positively correlated with diatom composition $(r=0.592, p<0.01)$.

\section{Amino Acid Composition of POM and Amino Acid Indices}

Particulate hydrolyzable AA concentrations were quantified from the sum of each measured concentration of 14 detected AA since tyrosine, cystine, and tryptophan were not detected in our POM samples (Table 5). The PAA concentrations within the euphotic zone ranged from $0.18 \mu \mathrm{M}$ at the $30 \%$ light depth of St. 2 to $1.04 \mu \mathrm{M}$ at the $30 \%$ light depth of St. 17, with an average value of $0.40 \pm 0.21 \mu \mathrm{M}$ (Table 5). However, the significant spatial distinction of PAA concentrations was not observed although the concentrations of biomolecular components had a clear spatial pattern as mentioned above. We calculated the carbon and nitrogen normalized yields of AAs (AA-POC\% and AA-PON\%) for our PAA samples (Table 5). The PAA accounted for 7.8-26.6\% of total POC (mean $\pm \mathrm{SD}=14.2 \pm 5.9 \%)$ and $21.3-81.8 \%$ of total $\mathrm{PON}$ (mean $\pm \mathrm{SD}=41.7 \pm 19.7 \%$ ), respectively (Table 5).

The contributions of each AA in the PAA are presented in Table 5. The AA composition in the PAA was variable among the stations, and especially lysine and histidine have substantial variability. The major constituents of the PAA were glycine, glutamic acid, and alanine whereas lysine, histidine, methionine, and phenylalanine were minor components (Table 5). Among individual $\mathrm{AA}$, glycine was the most dominant constituent (mean $\pm \mathrm{SD}=20.99 \pm 3.74 \%$ ), followed by glutamic acid, alanine, leucine, and serine. Lysine had the lowest molar percentage (mean $\pm \mathrm{SD}=2.78 \pm 2.93 \%)$ and particularly was below the detection limit in most samples obtained from Sts. 2 and 5. The percentage compositions of NEAA and EAA to total PAA were in the ranges of 46.5-65.3 and 34.7-53.5\%, respectively (Table 5). The proportion of NEAA was higher than those of the EAA fraction except for the sample at the 30\% light depth of St. 11 .

The calculated DI and EAAI values ranged from -0.87 to 1.00 and from 0.34 to 0.95 , respectively (Table 5). In this study, strong positive correlation was found between the relative contribution of EAA (\%) and EAAI (Figure 4; $r=0.629, p<0.01$ ).

\section{Multivariate Analysis (AHC Analysis and PCA) Between Biochemical (Biomolecular and Amino Acid) Compositions of POM and Other Chemical and Biological Features}

The dendrogram according to AHC analysis based on the same 28 variables used with PCA revealed three distinct groups (Figure 5). Cluster 1 (C1) had the southern part samples and one sample collected from 100\% light depth at St. 1 whereas Cluster 2 (C2) contained almost all the samples obtained from the northern 
TABLE 5 | PAA concentrations, carbon and nitrogen normalized yields of PAA (AA-POC\% and AA-PON\%), mol fractions of individual amino acids, NEAA, and EAA, and values of AA-based indices (DI and EAAI).

\begin{tabular}{|c|c|c|c|c|c|c|c|c|c|c|c|c|c|c|c|c|c|c|c|c|c|c|}
\hline \multirow[t]{2}{*}{ Station } & \multirow{2}{*}{$\begin{array}{l}\text { light } \\
\text { depth } \\
(\%)\end{array}$} & \multirow{2}{*}{$\begin{array}{l}\text { PAA } \\
(\mu \mathrm{M})\end{array}$} & \multirow{2}{*}{$\begin{array}{c}\text { AA- } \\
\text { POC } \%\end{array}$} & \multirow{2}{*}{$\begin{array}{c}\text { AA- } \\
\text { PON\% }\end{array}$} & \multicolumn{14}{|c|}{ Amino acid composition (mol\%) } & \multirow{2}{*}{$\begin{array}{c}\text { NEAA } \\
(\mathrm{mol} \%)\end{array}$} & \multirow{2}{*}{$\begin{array}{c}\text { EAA } \\
(\mathrm{mol} \%)\end{array}$} & \multirow[t]{2}{*}{ DI } & \multirow[t]{2}{*}{ EAAI } \\
\hline & & & & & ASP & GLU & SER & GLY & ALA & HIS & THR & ARG & VAL & MET & PHE & ILE & LEU & LYS & & & & \\
\hline \multirow[t]{3}{*}{1} & 100 & 0.30 & 9.6 & 28.9 & 6.40 & 14.48 & 7.67 & 17.98 & 8.83 & 3.59 & 7.69 & 6.14 & 5.94 & 1.51 & 3.92 & 4.31 & 7.62 & 3.94 & 55.4 & 44.6 & -0.10 & 0.87 \\
\hline & 30 & 0.61 & 21.3 & 76.9 & 6.61 & 18.01 & 7.64 & 22.86 & 8.98 & 4.03 & 3.00 & 8.18 & 3.77 & 2.48 & 2.54 & 3.50 & 7.24 & 5.52 & 64.1 & 40.3 & -0.72 & 0.83 \\
\hline & 1 & 0.61 & 24.0 & 81.8 & 4.65 & 10.33 & 9.45 & 25.39 & 6.87 & 4.04 & 7.23 & 7.67 & 4.13 & 4.33 & 3.59 & 3.62 & 8.68 & N.D. & 56.7 & 43.3 & -0.03 & 0.56 \\
\hline \multirow[t]{3}{*}{2} & 100 & 0.22 & 10.2 & 36.6 & 6.64 & 10.75 & 7.69 & 22.88 & 11.26 & 4.96 & 6.02 & 7.35 & 1.55 & 6.30 & 4.01 & 3.36 & 7.90 & N.D. & 59.2 & 41.5 & -0.11 & 0.51 \\
\hline & 30 & 0.18 & 7.8 & 23.6 & 6.31 & 10.06 & 7.84 & 20.74 & 13.30 & 6.04 & 4.30 & 5.82 & 1.72 & 7.16 & 4.32 & 4.28 & 8.11 & N.D. & 58.2 & 41.8 & 0.84 & 0.51 \\
\hline & 1 & 0.37 & 13.8 & 44.2 & 5.42 & 13.28 & 7.82 & 24.80 & 9.75 & 4.67 & 4.68 & 7.49 & 1.39 & 6.02 & 3.36 & 3.42 & 7.28 & N.D. & 61.1 & 38.3 & -0.02 & 0.51 \\
\hline \multirow[t]{3}{*}{5} & 100 & 0.21 & 8.2 & 21.3 & 9.65 & 11.71 & 8.68 & 24.90 & 10.38 & N.D. & 5.27 & 4.71 & 6.93 & 1.88 & 4.31 & 4.25 & 7.33 & N.D. & 65.3 & 34.7 & -0.54 & 0.34 \\
\hline & 30 & 0.46 & 18.8 & 59.1 & 7.57 & 15.38 & 6.71 & 23.69 & 7.65 & 5.49 & 4.11 & 7.04 & 1.26 & 4.90 & 4.00 & 3.04 & 3.33 & 9.68 & 61.0 & 42.8 & -0.04 & 0.71 \\
\hline & 1 & 0.43 & 20.7 & 56.3 & 7.63 & 20.28 & 6.05 & 22.23 & 7.62 & 6.59 & 3.44 & 7.06 & 2.31 & 1.50 & 3.87 & 3.23 & 8.18 & N.D. & 63.8 & 36.2 & 0.00 & 0.49 \\
\hline \multirow[t]{3}{*}{11} & 100 & 0.29 & 9.9 & 28.4 & 5.35 & 10.84 & 7.53 & 21.56 & 11.20 & 3.71 & 7.25 & 7.11 & 3.92 & 3.87 & 4.25 & 4.26 & 9.16 & N.D. & 56.5 & 43.5 & 0.29 & 0.57 \\
\hline & 30 & 0.26 & 10.4 & 27.1 & 10.01 & 13.38 & 8.14 & 14.97 & N.D. & 3.60 & 8.60 & 6.10 & 4.28 & 4.71 & 4.76 & 5.99 & 9.33 & 6.11 & 46.5 & 53.5 & 1.00 & 0.94 \\
\hline & 1 & 0.51 & 18.5 & 56.7 & 6.16 & 10.58 & 7.56 & 19.91 & 11.05 & 2.67 & 7.48 & 6.62 & 3.63 & 3.85 & 4.05 & 4.57 & 8.21 & 3.65 & 55.3 & 44.7 & 0.03 & 0.92 \\
\hline \multirow[t]{3}{*}{14} & 100 & 0.25 & 9.5 & 23.8 & 9.83 & 12.79 & 7.26 & 11.96 & 11.75 & N.D. & 7.51 & 4.64 & 4.46 & 5.00 & 4.27 & 6.18 & 8.39 & 6.44 & 53.6 & 46.9 & 0.45 & 0.57 \\
\hline & 30 & 0.25 & 10.0 & 27.9 & 6.67 & 11.27 & 7.53 & 18.04 & 10.71 & 4.23 & 6.75 & 5.72 & 4.75 & 3.39 & 3.92 & 4.85 & 7.91 & 4.26 & 54.2 & 45.8 & 0.24 & 0.95 \\
\hline & 1 & 0.29 & 10.5 & 28.3 & 7.17 & 12.84 & 7.96 & 16.48 & 11.05 & N.D. & 7.72 & 6.06 & 6.68 & 2.37 & 3.91 & 4.93 & 8.18 & 4.64 & 55.5 & 44.5 & -0.18 & 0.57 \\
\hline \multirow[t]{3}{*}{17} & 100 & 0.41 & 12.0 & 29.0 & 6.19 & 9.82 & 7.44 & 22.44 & 10.31 & 3.55 & 7.35 & 6.34 & 4.36 & 3.23 & 3.80 & 4.50 & 7.92 & 2.73 & 56.2 & 43.8 & -0.16 & 0.90 \\
\hline & 30 & 1.04 & 26.6 & 68.6 & 6.39 & 12.83 & 6.71 & 23.91 & 9.80 & 4.42 & 7.12 & 6.37 & 5.57 & 1.75 & 2.38 & 3.14 & 7.88 & 0.64 & 59.6 & 39.3 & -0.87 & 0.71 \\
\hline & 1 & 0.47 & 13.7 & 32.9 & 5.98 & 8.91 & 6.88 & 23.09 & 9.85 & 5.78 & 7.20 & 6.22 & 5.48 & 1.99 & 3.40 & 4.04 & 8.71 & 2.48 & 54.7 & 45.3 & -0.07 & 0.84 \\
\hline \multicolumn{2}{|c|}{ Mean \pm SD } & $\begin{array}{c}0.40 \pm \\
0.21\end{array}$ & $\begin{array}{c}14.2 \pm \\
5.9\end{array}$ & $\begin{array}{c}41.7 \pm \\
19.7\end{array}$ & $\begin{array}{c}6.92 \pm \\
1.52\end{array}$ & $\begin{array}{c}12.64 \pm \\
2.94\end{array}$ & $\begin{array}{c}7.59 \pm \\
0.76\end{array}$ & $\begin{array}{c}20.99 \pm \\
3.74\end{array}$ & $\begin{array}{c}9.46 \pm \\
2.85\end{array}$ & $\begin{array}{c}3.74 \pm \\
1.99\end{array}$ & $\begin{array}{c}6.26 \pm \\
1.68\end{array}$ & $\begin{array}{c}6.48 \pm \\
0.95\end{array}$ & $\begin{array}{c}4.01 \pm \\
1.78\end{array}$ & $\begin{array}{c}3.68 \pm \\
1.75\end{array}$ & $\begin{array}{c}3.85 \pm \\
0.60\end{array}$ & $\begin{array}{c}4.19 \pm \\
0.91\end{array}$ & $\begin{array}{c}7.85 \pm \\
1.27\end{array}$ & $\begin{array}{c}2.78 \pm \\
2.93\end{array}$ & $\begin{array}{c}57.6 \pm \\
4.5\end{array}$ & $\begin{array}{c}42.8 \pm \\
4.3\end{array}$ & $\begin{array}{c}0.00 \pm \\
0.47\end{array}$ & $\begin{array}{c}0.68 \pm \\
0.19\end{array}$ \\
\hline
\end{tabular}

The list of AA abbreviations is as follows: aspartic acid (ASP), glutamic acid (GLU), serine (SER), glycine (GLY), alanine (ALA), histidine (HIS), threonine (THR), arginine (ARG), valine (VAL), methionine (MET), phenylalanine (PHE), isoleucine (ILE), leucine (LEU), and lysine (LYS). 


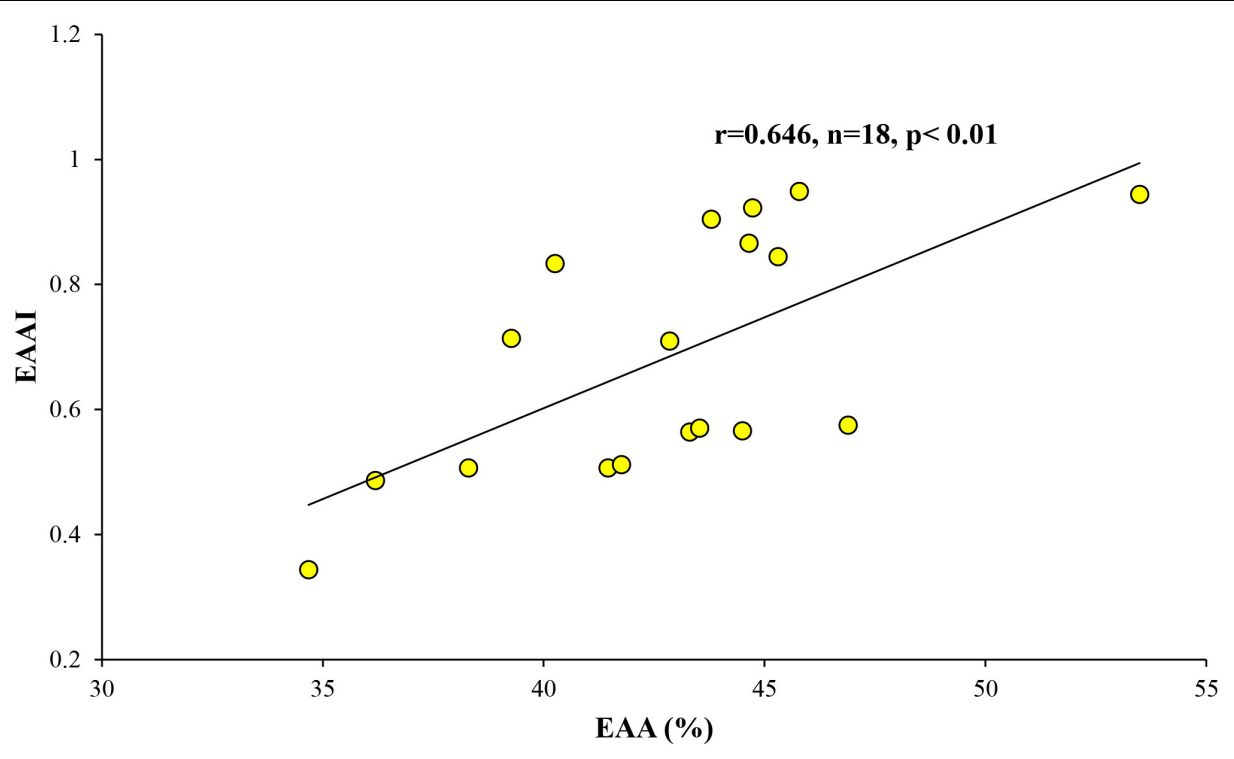

FIGURE 4 | Relationship between the relative contribution of EAA (\%) and EAAI.

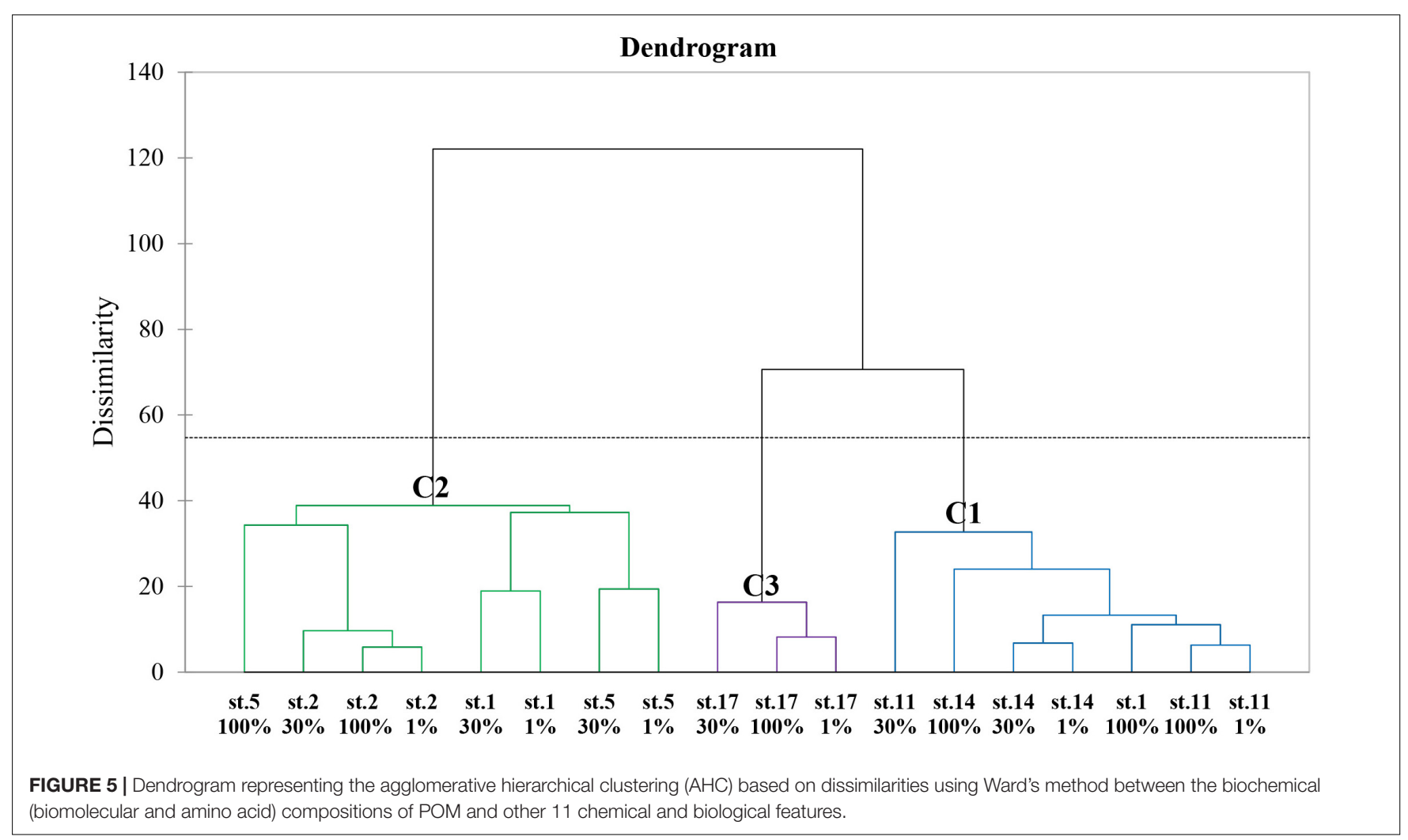

section. Cluster 3 (C3) included the samples collected from only St. 17 in the southern part. The maximum value of distances between the class centroids was observed between $\mathrm{C} 2$ and $\mathrm{C} 3$ (29.743), and C1 and C3 had a small difference in dissimilarity.

As a result of the PCA, the principal components (PC) 1 and 2 explained 29.30 and $21.41 \%$ of the data variance in the biochemical compositions and other parameters among the stations (Figure 6). The $\mathrm{PC} 1$ was positively correlated with $\mathrm{NO}_{2}+\mathrm{NO}_{3}, \mathrm{SiO}_{2}, \mathrm{C} / \mathrm{N}$ ratio, $\mathrm{CHO}$ composition (\%), $P$. antarctica, methionine, and serine whereas negatively loaded with Chl-a, PRT and LIP composition (\%), Diatoms, EAAI, and valine. The PC2 was found to be positively loaded with EAA composition (\%), isoleucine, threonine, phenylalanine, leucine, aspartic acid, and DI score while had negative loadings 
A

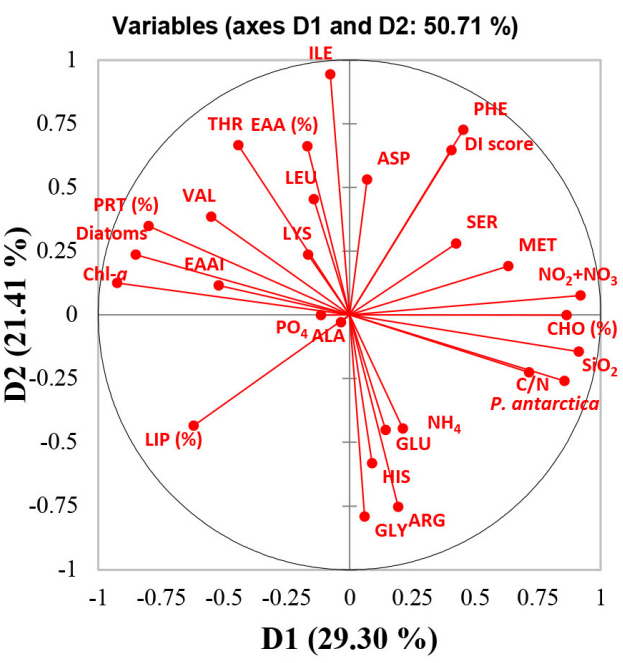

B

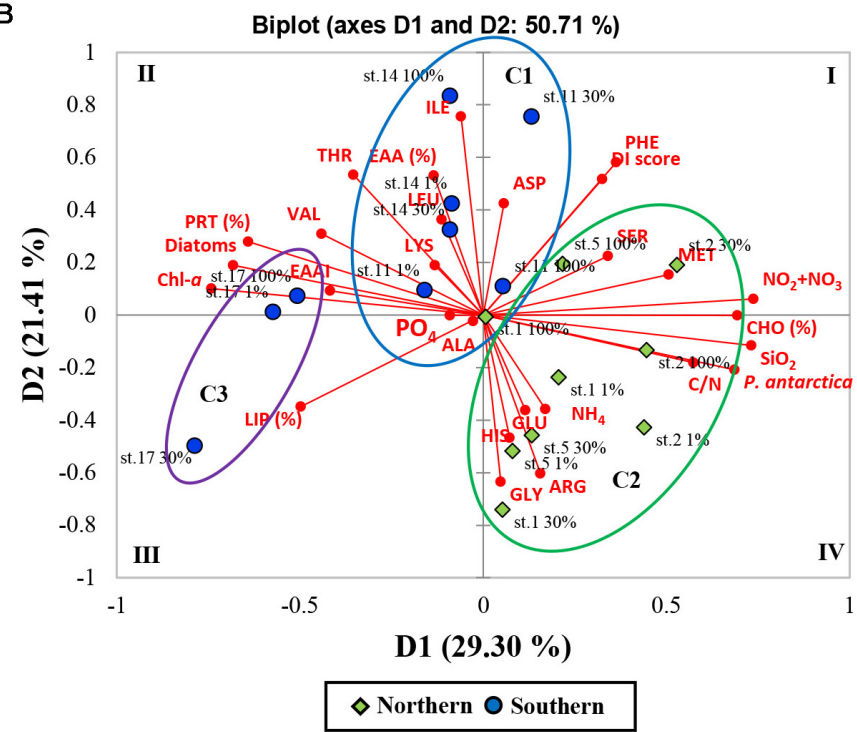

FIGURE 6 | Principal component analysis (PCA; after normalized varimax rotation) based on the biochemical (biomolecular and amino acid) compositions of POM and other chemical and biological features. (A) Correlation circle and projection obtained by PCA of the 28 variables; each red arrow represents the squared cosine corresponding to an individual variable. (B) Biplot of PCA on the 28 variables and observations for the first and second axis (variability explained: 50.71\%).

Observations are grouped according to the classes obtained from agglomerative hierarchical clustering (AHC). Each abbreviation represents as aspartic acid (ASP), glutamic acid (GLU), serine (SER), glycine (GLY), alanine (ALA), histidine (HIS), threonine (THR), arginine (ARG), valine (VAL), methionine (MET), phenylalanine (PHE), isoleucine (ILE), leucine (LEU), lysine (LYS), compositions of essential amino acids (EAAs), essential amino acid index (EAAI), degradation index (DI), relative contributions of diatoms (Diatoms) and haptophytes (P. antarctica), biomolecular composition ( $\mathrm{CHO}, \mathrm{PRT}$, and LIP), carbon to nitrogen ratio (C:N), phosphate (PO 4$)$, nitrate + nitrite $\left(\mathrm{NO}_{2}+\mathrm{NO}_{3}\right)$, ammonium $\left(\mathrm{NH}_{4}\right)$, silicate $\left(\mathrm{SiO}_{2}\right)$, and chlorophyll a $(\mathrm{Chl}-a)$.

for glycine, arginine, and histidine. To determine whether correlations were worthy of interpretation, we examined the squared cosines of the variables and then excluded low values of squared cosines between the variables and PCs (Figure 6; i.e., glutamic acid, alanine, lysine, $\mathrm{PO}_{4}$, and $\mathrm{NH}_{4}$ ). A distinct spatial separation between the northern and southern parts of our study area was founded along the PC1 axis. In other words, most of the samples collected from the southern part were on the left side of the biplot (quadrants II and III) whereas most of the northern part samples were placed on the lower righthand side (quadrant IV). Moreover, the observations in the PCA space showed a similar pattern of clustering as the AHC analysis (Figures 5, 6).

\section{DISCUSSION}

\section{Source of the Bulk POM}

The marine POM filtered on filter paper includes diverse organic matter derived from phytoplankton, bacterial plankton, detritus, and terrestrial organic matter (Harmelin-Vivien et al., 2008). Both of $\mathrm{C} / \mathrm{N}$ molar ratio and $\delta^{13} \mathrm{C}$ value in bulk POM have long been used as indicators of the nature of the organic matter in various marine ecosystems (Wada et al., 1975; Zweifel et al., 1993; Montagnes et al., 1994; Lee and Whitledge, 2005). Generally, phytoplankton have higher $\mathrm{C} / \mathrm{N}$ ratios in a range of $6-10$ than bacteria (3-5), whereas terrestrial organic matters have 2-20 times higher than the $\mathrm{C} / \mathrm{N}$ values of phytoplankton (Brzezinski,
1985; Montagnes et al., 1994; Tyson, 1995; Goñi et al., 2003; Lamb et al., 2006). The range of $\mathrm{C} / \mathrm{N}$ molar ratios of 7.7-11.4 (mean \pm S.D $=9.6 \pm 1.0$ ) for POM in this study is within the previously reported range of $\mathrm{C} / \mathrm{N}$ ratio for phytoplankton (Table 2). However, Fabiano et al. (1993) reported lower C/N molar ratios within the euphotic zone than our observation, ranging from 5.4 and 9.1 at the stations near Cape Adare and 5.4-6.6 at the stations located in Terra Nova Bay, Ross Sea. Moreover, Coale et al. (2003) obtained slightly lower ratios ranging from 6.5 to 7.9 in the southern Ross Sea. Generally, lower $\mathrm{C} / \mathrm{N}$ ratios within the euphotic layer were reported during the bloom period in Antarctic water according to previous studies (Bodungen et al., 1986; Nelson et al., 1989; Fabiano et al., 1993). The relatively higher values of the $\mathrm{C} / \mathrm{N}$ ratio in this study could be due to our sampling period conducted at the end of February 2018 in a post-bloom period which will be discussed later.

In general, $\delta^{13} \mathrm{C}$ values derived from marine phytoplankton range from -23 to $-19 \%$ (Fry and Sherr, 1989; HarmelinVivien et al., 2008). In comparison, $\delta^{13} \mathrm{C}$ values in phytoplankton communities of Antarctic surface waters are lower than those observed in lower-latitude oceans (Wada et al., 1987; Rau et al., 1989, 1991; Dehairs et al., 1997). In this study, the $\delta^{13} \mathrm{C}$ values in the surface bulk POM were in a range of -29.2 to $-25.1 \%$ (mean $\pm \mathrm{SD}=-26.9 \pm 1.3 \%$ ) (Table 2 ). Although our study has $\delta^{13} \mathrm{C}$ values closer to terrestrial organic matters ( -30 to $-26 \%$; Fry and Sherr, 1989), previous studies have reported that input of terrestrial organic matter from the ice-covered continent is 
negligible in the Ross Sea (Rogers and Dunbar, 1993; Villinski et al., 2000). Based on the results of both $\mathrm{C} / \mathrm{N}$ ration and $\delta^{13} \mathrm{C}$ values of POM, the main source of POM in this study could be phytoplankton-derived organic matter.

\section{Biomolecular Composition of POM}

In general, the temporal dynamics of the two major types of phytoplankton blooms have been well documented in the Ross Sea (Arrigo et al., 1999; Smith et al., 2000, 2011). The initial bloom dominated by the haptophyte $P$. antarctica is commonly found in the south-central Ross Sea during austral spring (Peloquin and Smith, 2007). The following second bloom dominated by diatoms commonly is observed in the western and eastern portions of the Ross Sea in summer (DiTullio and Smith, 1996; Peloquin and Smith, 2007). Considering temporal and spatial phytoplankton bloom patterns in the northwestern Ross Sea, we infer that our sampling period (end of February-the beginning of March) was in the post-bloom. In the present study, haptophytes dominated by solitary $P$. antarctica cells and nano-sized diatom assemblages with low chl- $a$ concentrations $\left(<0.6 \mu \mathrm{g} \mathrm{L}^{-1}\right)$ and high POC/Chl- $a$ values potentially indicate mostly inactive cells (Mangoni et al., 2017) prevailed in the northern part of the study area (Tables 2, 3). Smith et al. (2003) reported that the abundance of solitary $P$. antarctica cells increases in the Ross Sea during late summer under inorganic nutrient and/or iron limitation. Furthermore, Mathot et al. (2000) and Shields and Smith (2009) suggested that colonial P. antarctica cells can be associated with their maximum biomass under nutrient-replete conditions and exponential phase whereas solitary $P$. antarctica cells numerically dominate when their growth rate declined and the senescence phase began after bloom. In this study, the microsized diatoms with their elevated chl- $a$ concentrations (up to $1.5 \mu \mathrm{g} \mathrm{L}^{-1}$ ) and low POC/Chl- $a$ values indicate relatively active cells (Mangoni et al., 2017) predominated in the southern part (Tables 2, 3) in comparison to the northern part. Therefore, taking into account the bloom phase and biological features (phytoplankton community, cell size, chl- $a$ concentration, and $\mathrm{POC} /$ Chl- $a$ value), it seems reasonable to suggest that solitary $P$. antarctica cells and nano-sized diatoms observed in the northern section were in a senescent status, while micro-sized diatoms dominated in the southern section were in a relatively active condition.

There have been numerous studies published in the literature that the synthesis of biomolecular classes could be influenced by different growth phases of phytoplankton (Moal et al., 1987; Fernández-Reiriz et al., 1989; de Madariaga, 1992; Ríos et al., 1998; Ahn et al., 2019). Considerable changes in the biomolecular composition of the phytoplankton occurred throughout different growth phases (i.e., exponential, stationary, and senescent phases) (Ahn et al., 2019 and the references therein). The amounts of PRT as biomolecular products of photosynthesis increased during the exponential growth phase, indicating a higher PRT demand for exponential cell division and growth (Mayzaud et al., 1990; Berdalet et al., 1994). When phytoplankton become stationary and senescent conditions concurrent with the nutrient deficiency thereafter, $\mathrm{CHO}$ and LIP levels increase for energy reserves (Myklestad, 1974; Mague et al., 1980; Barlow,
1982; Tonon et al., 2002). Generally, phytoplankton growth in the Ross Sea is limited by irradiance during austral spring (Smith et al., 2000; Peloquin and Smith, 2007), but by nutrient bioavailability (particularly iron) in austral summer (Sedwick and Ditullio, 1997; Sedwick et al., 2000; Peloquin and Smith, 2007). In this study, major inorganic nutrient concentrations (phosphate, nitrate + nitrite, ammonium, and silicate) in seawater were not depleted (Figure 3). Furthermore, $\mathrm{Si}^{*}$ (defined as $[\mathrm{Si}]-\left[\mathrm{NO}_{3}{ }^{-}\right]$ in $\mu \mathrm{M})$ for the identification of potential iron limitation had positive values from all stations, suggesting that there was no evidence for iron limitation during this study (Sarmiento et al., 2004; Le Moigne et al., 2013). However, scarcity of iron is a very common feature in the Ross Sea during the summer season (Olson et al., 2000; Smith and Asper, 2001), and Si* could be restricted as a community-wide iron limitation index because $\mathrm{Si}^{*}$ represents the silicic acid uptake and growth related to only diatom communities under iron limitation (Hogle et al., 2018; Louropoulou et al., 2019). On the other hand, the specific carbon uptake rates of phytoplankton in parallel with our study were highest at surface water from all stations, which suggests potential light limited conditions in late austral summer period (Lee et al., 2008). Hence, phytoplankton during this study could have been a physiologically inactive condition under unfavorable environmental conditions.

In our study, $\mathrm{CHO}$ accounted for the highest portion (mean $\pm \mathrm{SD}=54.0 \pm 10.2 \%)$ among different biomolecules (CHO, PRT, and LIP) of POM (Table 4). However, the higher contribution of PRT (up to 27.2\%) and lower contribution of $\mathrm{CHO}$ were observed in the southern section of our study area compared to those in the northern section (Table 4). Furthermore, we found significant differences in $\mathrm{CHO}$ and PRT compositions between the northern and southern stations ( $t$ test, $p<0.05)$. These discrepancies could explain that CHOrich solitary $P$. antarctica cells and nano-sized diatoms were in a senescent phase in the northern part whereas micro-sized diatoms having relatively higher PRT had more active conditions in the southern part. On the other hand, marked spatial variations in biomolecular compositions among the stations were probably due to taxonomic differences. The composition of CHO-rich POM may be linked with structural and/or storage CHO synthesis of $P$. antarctica (Lancelot and Mathot, 1985; Alderkamp et al., 2007; Mangoni et al., 2017; Kim et al., 2018). $P$. antarctica produces a mucous colony matrix which is mostly composed of polysaccharides as a kind of structural $\mathrm{CHO}$ (Alderkamp et al., 2007; Mangoni et al., 2017). Hong et al. (1997) suggested that when $P$. antarctica colony matrix begins to break up during the senescent phase, transparent exopolymer particle (TEP) production by $P$. antarctica is closely related with increased particulate $\mathrm{CHO}$. Moreover, $\mathrm{CHO}$ accumulation has been observed when both single-cell and colonial $P$. antarctica reach the end of the bloom phase since they store the surplus energy as storage CHO (Lancelot and Mathot, 1985; Alderkamp et al., 2007 and the references therein). In contrast, Young et al. (2015a) found that Antarctic diatoms adapted to cold temperatures tend to increase PRT concentrations to compensate for slow enzyme rates. In conclusion, spatial variability of the biomolecular composition in the bulk POM during this study was 
not only influenced by phytoplankton growth phases but also by those taxonomic compositions.

\section{Influence of Origin and Degradation Status on the Amino Acid Composition of POM}

The measured concentrations of the PAA during this study (Table 5; 0.18-1.04 $\mu \mathrm{M}$ ) varied significantly but were in agreement well with the range of values previously reported from polar regions (Hubberten et al., 1995; Dittmar et al., 2001; Tsukasaki and Tanoue, 2010; Tremblay et al., 2015). Based on the Antarctic data (Weddell Sea), Hubberten et al. (1995) found relatively higher PAA concentrations $(0.75 \pm 0.60 \mu \mathrm{M})$ averaged in the upper $100 \mathrm{~m}$ depth than those reported in the Arctic water (mean $\pm \mathrm{SD}=0.57 \pm 0.61 \mu \mathrm{M}$ ). Tremblay et al. (2015) observed higher concentrations of PAA at the most productive stations (up to $0.82 \mu \mathrm{M}$ ) while lower concentrations of PAA (0.16$0.22 \mu \mathrm{M})$ at the stations with low phytoplankton biomass in the Southern Ocean. Our results are also consistent with that the positive relationship between PAA and total chl- $a$ concentrations $(r=0.510, p<0.05)$. Therefore, the source of PAA in this study is probably mostly phytoplankton-produced PRT (Kalachova et al., 2004 and the references therein).

It is well known that AAs in hydrolyzed POM accounted for approximately $30 \%$ of POC and $50 \%$ of PON in various oceans (Handa, 1970; Siezen and Mague, 1978; Liebezeit and Bölter, 1986; Misic et al., 2017). All of the AA contributions to POC (Table 5; 7.8-26.6\% of total POC) in the present study are lower than those in previous studies (Handa, 1970; Siezen and Mague, 1978; Liebezeit and Bölter, 1986). In contrast, the averaged proportions of AA to PON (mean \pm SD $=41.7 \pm 19.7 \%$ of total PON) are comparable to those in previous studies (Handa, 1970; Siezen and Mague, 1978; Liebezeit and Bölter, 1986), although they varied greatly (21.3-81.8\% of total PON) (Table 5). According to Shields et al. (2019), the carbon normalized yield of AAs (AA-POC\%) had higher values in less degraded organic matter and decreased with degradation. In other words, values of AA-POC\% were highest during the mid-exponential bloom phase, while they decreased in the stationary and degradation phases of phytoplankton growth (Shields et al., 2019). Furthermore, AA-PON\% could also be indicated for diagenesis in phytoplankton (Duan and Bianchi, 2007). Therefore, the relatively low AA contributions to the total POC and PON in this study imply that the majority of PAA might have undergone degradation to some degree (Duan and Bianchi, 2007; Shields et al., 2019).

The major constituents of PAA during this cruise were glycine, glutamic acid, and alanine, occupying $43.1 \%( \pm 5.1 \%)$ of total PAA in the bulk POM (Table 5). Generally, previous studies reported that the predominant AAs of phytoplankton are glutamic acid, aspartic acid, alanine, and leucine regardless of marine or freshwater species although there are little differences in the AA composition of phytoplankton depending on the species (Hayashi et al., 1986 and the references therein). However, Hecky et al. (1973) suggested that serine + threonine and glycine could be enriched in the cell wall PRT of diatoms. We found that mol\% serine + threonine only positively correlated with diatom composition $(r=0.473, p<0.05)$ while mol\% glycine had no correlation with diatoms. Although the correlation directly with diatoms was poor as diatom frustules can be preferentially preserved after cell death, glycine and serine were found to be bounded on the diatom frustules and this may be a reason why glycine was enriched in the POM (Ingalls et al., 2006). On the other hand, Liebezeit and Bölter (1986) found that glutamic acid, aspartic acid, glycine, and serine are the most dominant compounds of phytoplankton-derived PAA whereas glycine becomes dominant in the PAA of deeper waters with an appreciable quantity of detrital materials. Thus, the composition of PAA was caused by the combined effects of diatom-dominated phytoplankton communities and phytodetritus in this study after the bloom. Further evidence for supporting the degraded POM in our study was relatively low DI values of PAA (Table 5). Over half of calculated DI scores for our PAA samples showed negative values indicating that PAA appeared to be highly degraded phytodetritus (Dauwe et al., 1999; Wu et al., 2007; Shields et al., 2019). In general, the DI scores can provide information on the degree of degradation in bulk POM (Dauwe et al., 1999; Wu et al., 2007; Shields et al., 2019). The more negative DI value indicates the more degraded condition, while a positive DI value is indicative of fresh phytoplankton (Dauwe et al., 1999; Wu et al., 2007; Shields et al., 2019).

\section{The Potential Impacts of the AA Composition on Food Quality for Zooplankton Nutrition}

The nutritional quality of PRT can be estimated by the proportion of total EAA and EAAI (Mente et al., 2002; Ju et al., 2008). As shown in Table 5, total EAA contributed $42.8 \pm 4.3 \%$ during this study, which is within the range (41-55\%) of compositional data on the EAA of microalgae and cyanobacteria conducted both in laboratory cultures and natural conditions (Kolmakova and Kolmakov, 2019 and the references therein). The general profile for individual EAA of phytoplankton composed high contributions of leucine and arginine whereas methionine and histidine were significantly lower than other EAA (Kolmakova and Kolmakov, 2019 and the references therein). In this study, however, lysine and histidine were limited in our POM samples collected from some stations with concurrent lower values of the EAAI (Table 5). EAAI scores can be evaluated for protein quality by comparing the geometric mean value of EAA in an FM relative to a reference protein derived from consumers (Peñaflorida, 1989). Based on the classification of Oser (1959), scores of the calculated EAAI over 0.9 are defined as good protein material, EAAI of approximately 0.8 is indicated as a useful protein, and EAAI below 0.7 can be classified as inadequate PRT. Thus, efficient protein food can be considered by the most similar AA profile between prey and their consumer and EAAI scores approaching 1.0 (Ju et al., 2008). The mean EAAI $(0.68 \pm 0.19)$ was classified as inadequate protein FMs during this study although the scores of the total EAAI (0.34-0.95) varied significantly (Table 5). Based on the results of EAA in this study, we found that significant positive relationship between 
the proportion of EAA and AA EAAI (Figure 4). This result may be surmised that a greater proportion of EAA in POM was composed with EAA composition with balanced in an optimal proportion.

Anderson et al. (2004) suggested that individual EAA-deficient diets had a greater impact on the limitation of the growth of higher trophic levels rather than bulk amounts of protein and nitrogen. The previously published studies found that imbalances in dietary EAA could cause a bad influence on the growth of marine zooplankton (Kleppel et al., 1998; Guisande et al., 2000). Furthermore, the total AA composition of the copepod diets, as well as EAA composition, can be important for the higher reproductive success of copepods (Guisande et al., 2002). According to Guisande et al. (2000), AA from ingested food could not be converted into consumer's biomass for egg production with an optimal proportion of AA if AA composition in prey is highly dissimilar to that of female copepods. Thus, the higher reproductive success of female copepods is observed when the AA composition of the ingested food is similar to that of the consumers (Guisande et al., 1999, 2000). In this study, we compared the averaged each AA profile of two phytoplankton communities that were divided into diatoms-dominant (Sts. 1, 11,14 , and 17) and relatively higher $P$. antarctica-abundant communities (Sts. 2 and 5) with those of bulk zooplankton communities (unpublished data) (Figure 7). The reason why we separated into two groups is that variable grazing by herbivores appears to discriminate based on the food quality, preference of ingesting cells, and distributions of the phytoplankton community (Haberman et al., 2003 and the references therein). In addition, lysine was nearly absent throughout the euphotic zone at $P$. antarctica-abundant stations 2 and 5 (Table 5). Assuming that the same assimilation rates of total AA between the two groups, we observed that the relationship for the diatomsdominant group was closer to the 1:1 line considered as the ideal line in comparison to $P$. antarctica-abundant group with greater deviations of glycine, lysine, valine, methionine, and histidine from the line (Figure 7). Therefore, it seems reasonable to suggest that diatoms-dominant diets were better protein sources because they had an AA composition similar to their consumers and higher EAAI value. Our findings are also consistent with the conclusions of Boyd (1989) and Burford (1997).

\section{The Application of Multivariate Statistical Analysis for Evaluating Food Quality for Consumers}

In this work, the multivariate statistical analysis was conducted for finding relationships between biochemical compositions (biomolecular and AA compositions) and other chemical and biological data. The PC1 of PCA results separated two different groups of biochemical parameters and phytoplankton communities. These two groups formed high proportions of $\mathrm{CHO}$ and high $\mathrm{C} / \mathrm{N}$ values with a haptophytes-abundant group dominated by solitary $P$. antarctica cells while relatively higher

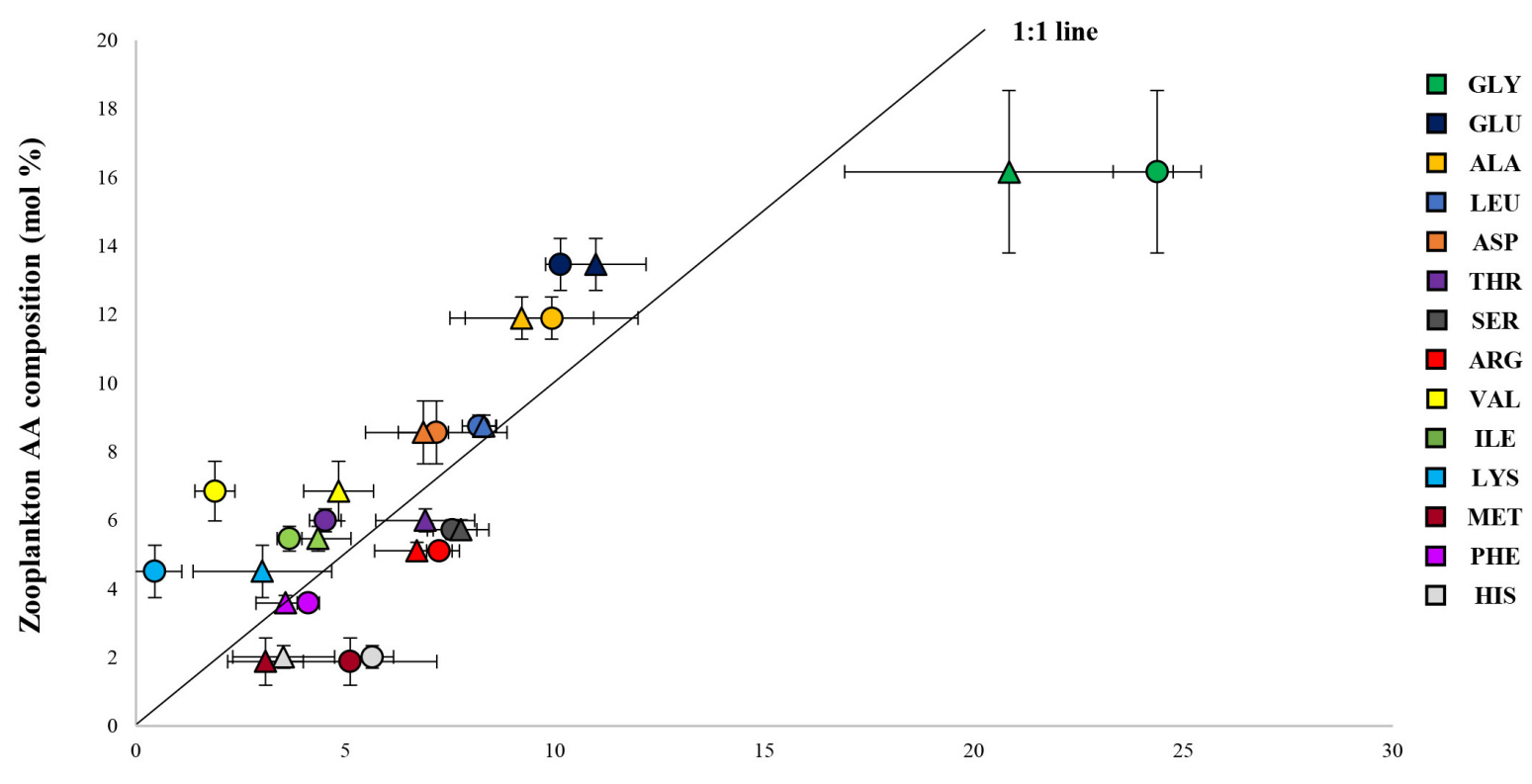

Phytoplankton AA composition (mol \%)

$$
\triangle \text { Diatom-dominated } \bigcirc \text { P.antartica-abundant }
$$

FIGURE 7 | Relationship between amino acid profiles of diatom-dominant and $P$. antartica-abundant communities and those in zooplankton communities as potential consumers. Each abbreviation represents aspartic acid (ASP), glutamic acid (GLU), serine (SER), glycine (GLY), alanine (ALA), histidine (HIS), threonine (THR), arginine (ARG), valine (VAL), methionine (MET), phenylalanine (PHE), isoleucine (ILE), leucine (LEU), and lysine (LYS). 
proportions of PRT and high EAAI scores with diatom-dominant communities (Figure 6). In the PC2, EAA composition and DI score were negatively related to glycine which is considered as an indicator of organic matter degradation as discussed above (Figure 6) (Liebezeit and Bölter, 1986; Petersson and Floderus, 2001). Overall, our results revealed that the southern region dominated majorly by micro-sized diatoms was positively correlated with PRT, EAA, and EAAI indicating a good protein quality, while the relatively solitary $P$. antarctica-abundant northern region with higher $\mathrm{CHO}$ contribution was negatively correlated with good protein quality factors.

\section{CONCLUSION}

Our study found remarkable differences in biochemical compositions (biomolecular and AA compositions) of the phytoplankton communities (i.e., $\mathrm{CHO}$-rich vs. relatively higher PRT and good vs. bad protein quality) depending upon the growth phase and community structure of phytoplankton. These changes in the biochemical compositions (biomolecular and AA compositions) and protein quality of phytoplankton as a valuable nutrition source could be important for the growth, reproduction, and naupliar survival of herbivorous zooplankton as well as their biochemical composition (Gulati and Demott, 1997; Guisande et al., 2000; Vargas et al., 2006; Yun et al., 2015; Jo et al., 2017). Furthermore, differences in biochemical compositions of POM could also influence the degree of subsequent bacterial degradation and recycling since the lability of individual biochemical compounds varies widely (Harvey et al., 1995; Ingalls et al., 2006; Sabadel et al., 2019; Lehmann et al., 2020). The more refractory compounds could be preserved highly selective with the loss of labile compounds through the microbial process, thereby changing the biochemical compositions of sinking particles and consequently in sediments (Harvey et al., 1995; Alkhatib et al., 2012; Lehmann et al., 2020). Recently, significant changes in physical conditions such as increasing summer temperatures in the atmosphere and surrounding waters were observed in the southwestern Ross Sea continental shelf and lengthening of the free ice season was found in Ross Sea polynya induced by climate change (Stammerjohn et al., 2008; Comiso et al., 2011; Schine et al., 2016; Kaufman et al., 2017). These climate-induced stressors can lead to changes in the size structure and assemblage composition of phytoplankton and physiological shifts in the phytoplankton communities (Yun et al., 2019; Antoni et al., 2020; Hernando et al., 2020). Moreover, herbivores encounter rapidly changing food quality in company with changes in the diverse species, quantity, and biochemical characteristics of their prey (Scott,

\section{REFERENCES}

Ahn, S. H., Whitledge, T. E., Stockwell, D. A., Lee, J. H., Lee, H., and Lee, S. H. (2019). The biochemical composition of phytoplankton in the Laptev and East Siberian seas during the summer of 2013. Polar Biol. 42, 133-148. doi: 10.1007/ s00300-018-2408-0

Ainley, D., Russell, J., Jenouvrier, S., Woehler, E., Lyver, P. O. B., Fraser, W. R., et al. (2010). Antarctic penguin response to habitat change as earth's troposphere
1980; Finkel et al., 2010). In addition, differential preservation of biochemical compounds in accordance with reactive changes of the altered biochemical composition of POM under ongoing climate changes could have effects on remineralization rates and sinking particles in the deep sea (Ingalls et al., 2006; Kharbush et al., 2020; Lehmann et al., 2020). Therefore, additional research with multidiscipline approaches is required to evaluate the important food quality as a food source for higher trophic level organisms and understand complicated biochemical parameters associated with climate changes.

\section{DATA AVAILABILITY STATEMENT}

The original contributions presented in the study are included in the article/Supplementary Material. Further inquiries can be directed to the corresponding author/s.

\section{AUTHOR CONTRIBUTIONS}

SL, NJ, and J-HK contributed to conceptualization. NJ, HL, KK, $\mathrm{BK}$, and $\mathrm{MK}$ contributed to data curation. NJ, KK, BK, MK, and WS contributed to sample analysis. NJ, HL, J-HK, BK, and WS contributed to investigation. SL, NJ, and KK contributed to methodology and data validation. HL and J-HK gave scientific advice. NJ and SL contributed to writing-original draft. NJ, HL, and SL contributed to writing-review and editing. All authors agreed with the submission of the manuscript, and read and agreed to the published version of the manuscript.

\section{FUNDING}

This research was supported by the "Ecosystem Structure and Function of Marine Protected Area (MPA) in Antarctica” project (PM20060), funded by the Ministry of Oceans and Fisheries (20170336), South Korea.

\section{SUPPLEMENTARY MATERIAL}

The Supplementary Material for this article can be found online at: https://www.frontiersin.org/articles/10.3389/fmicb. 2021.623600/full\#supplementary-material

Supplementary Figure 1 | Representative chromatogram for L-amino acids mixed standard; 1: ASP, 2: GLU, 3: ASN, 4: SER, 5: GLN, 6: HIS, 7: GLY, 8: THR, 9: ARG, 10.ALA, 11: TYR, 12: CY2, 13: VAL, 14: MET, 15: NVA, 16: TRP, 17: PHE, 18: ILE, 19: LEU, and 20: LYS.

reaches $2^{\circ} \mathrm{C}$ above preindustrial levels. Ecol. Monogr. 80, 49-66. doi: 10.1890/ 08-2289.1

Alderkamp, A. C., Buma, A. G. J., and Van Rijssel, M. (2007). The carbohydrates of phaeocystis and their degradation in the microbial food web. Biogeochemistry 83, 99-118. doi: 10.1007/978-1-4020-6214-8_9

Alderkamp, A. C., Kulk, G., Buma, A. G. J., Visser, R. J. W., Van Dijken, G. L., Mills, M. M., et al. (2012). The effect of iron limitation on the photophysiology of phaeocystis antarctica (prymnesiophyceae) and fragilariopsis cylindrus 
(bacillariophyceae) under dynamic irradiance. J. Phycol. 48, 45-59. doi: 10. 1111/j.1529-8817.2011.01098.x

Alkhatib, M., Schubert, C. J., Del Giorgio, P. A., Gelinas, Y., and Lehmann, M. F. (2012). Organic matter reactivity indicators in sediments of the St. Lawrence Estuary. Estuar. Coast. Shelf Sci. 10, 36-47. doi: 10.1016/j.ecss.2012.03. 002

Anderson, T. R., Boersma, M., and Raubenheimer, D. (2004). Stoichiometry: linking elements to biochemicals. Ecology 85, 1193-1202. doi: 10.1890/020252

Andersson, A., Tamminen, T., Lehtinen, S., Jürgens, K., Labrenz, M., and Viitasalo, M. (2017). "The pelagic food web," in Radziejewska. Biological Oceanography of the Baltic Sea, eds P. Snoeijs-Leijonmalm and H. Schubert (Berlin: Springer), 281-332.

Antoni, J. S., Almandoz, G. O., Ferrario, M. E., Hernando, M. P., Varela, D. E., Rozema, P. D., et al. (2020). Response of a natural Antarctic phytoplankton assemblage to changes in temperature and salinity. J. Exp. Mar. Bio. Ecol. 532:151444. doi: 10.1016/j.jembe.2020.151444

Arrigo, K. R., Robinson, D. H., Worthen, D. L., Dunbar, R. B., DiTullio, G. R., VanWoert, M., et al. (1999). Phytoplankton community structure and the drawdown of nutrients and CO2 in the Southern ocean. Science 283, 365-367. doi: $10.1126 /$ science. 283.5400 .365

Asper, V. L., and Smith, W. O. (2019). Variations in the abundance and distribution of aggregates in the Ross sea. Antarctica. Elementa 7:23. doi: 10.1525/ elementa.355

Barlow, R. G. (1982). Phytoplankton ecology in the Southern Benguela current. III. dynamics of a bloom. J. Exp. Mar. Bio. Ecol. 165, 171-189.

Bartolomeo, M. P., and Maisano, F. (2006). Validation of a reversed-phase HPLC method for quantitative amino acid analysis. J. Biomol. Tech. 17, 131-137.

Basu, S., and Mackey, K. R. M. (2018). Phytoplankton as key mediators of the biological carbon pump: their responses to a changing climate. Sustain 10:1. doi: 10.3390/su10030869

Becker, W., and Richmond, A. (2004). "Microalgae in human and animal nutrition," in Handbook of Microalgal Culture Biotechnology Applied Phycology (London: Blackwell Science).

Berdalet, E., Latasa, M., and Estrada, M. (1994). Effects of nitrogen and phosphorus starvation on nucleic acid and protein content of Heterocapsa sp. J. Plankton Res. 16, 303-316. doi: 10.1093/plankt/16.4.303

Bhavya, P. S., Kim, B. K., Jo, N., Kim, K., Kang, J. J., Lee, J. H., et al. (2019). A review on the macromolecular compositions of phytoplankton and the implications for aquatic biogeochemistry. Ocean Sci. J. 54, 1-14. doi: 10.1007/s12601-0180061-8

Bligh, E. G., and Dyer, W. J. (1959). A rapid method of total lipid extraction and purification. Can. J. Biochem. Physiol. 37, 911-917. doi: 10.1139/059-099

Bodungen, B. V., Smetacek, V. S., Tilzer, M. M., and Zeitzschel, B. (1986). Primary production and sedimentation during spring in the Antarctic Peninsula region. Deep Sea Res. Part A Oceanogr. Res. Pap. 33, 177-194. doi: 10.1016/01980149(86)90117-2

Boyd, C. E. (1989). Water Quality Management and Aeration in Shrimp Farming. Fisheries and Allied Aquaculture Departmental. Series No. 2. Auburn, AL: Auburn University, Alabama Agricultural Experiment Station, 83.

Bracegirdle, T. J., and Stephenson, D. B. (2012). Higher precision estimates of regional polar warming by ensemble regression of climate model projections. Clim. Dyn. 39, 2805-2821. doi: 10.1007/s00382-012-1330-3

Bracegirdle, T. J., Connolley, W. M., and Turner, J. (2008). Antarctic climate change over the twenty first century. J. Geophys. Res. Atmos. 8:D03103. doi: 10.1029/2007JD008933

Brzezinski, M. A. (1985). The Si: C: $\mathrm{N}$ ratio of marine diatoms: interspecific variability and the effect of some environmental variables 1. J. Phycol. 21, 347-357. doi: 10.1111/j.0022-3646.1985.00347.x

Burford, M. (1997). Phytoplankton dynamics in shrimp ponds. Aquac. Res. 28, 351-360. doi: 10.1111/j.1365-2109.1997.tb01052.x

Coale, K. H., Wang, X., Tanner, S. J., and Johnson, K. S. (2003). Phytoplankton growth and biological response to iron and zinc addition in the Ross Sea and Antarctic circumpolar current along $170^{\circ}$ W. Deep. Res. Part II Top. Stud. Oceanogr. 50, 635-653. doi: 10.1016/S0967-0645(02)00588-X

Comiso, J. C., Kwok, R., Martin, S., and Gordon, A. L. (2011). Variability and trends in sea ice extent and ice production in the Ross sea. J. Geophys. Res. Oceans 116:C04021. doi: 10.1029/2010JC006391
Cowie, G. L., and Hedges, J. I. (1992). Improved amino acid quantification in environmental samples: charge-matched recovery standards and reduced analysis time. Mar. Chem. 37, 223-238. doi: 10.1016/0304-4203(92)90079-p

Danovaro, R., Dell'Anno, A., Pusceddu, A., Marrale, D., Della Croce, N., Fabiano, M., et al. (2000). Biochemical composition of pico-, nano- and microparticulate organic matter and bacterioplankton biomass in the oligotrophic Cretan sea (NE Mediterranean). Prog. Oceanogr. 46, 279-310. doi: 10.1016/ s0079-6611(00)00023-9

Dauwe, B., and Middelburg, J. J. (1998). Amino acids and hexosamines as indicators of organic matter degradation state in North sea sediments. Limnol. Oceanogr. 43, 782-798. doi: 10.4319/lo.1998.43.5.0782

Dauwe, B., Middelburg, J. J., Herman, P. M. J., and Heip, C. H. R. (1999). Linking diagenetic alteration of amino acids and bulk organic matter reactivity. Limnol. Oceanogr. 44, 1809-1814. doi: 10.4319/lo.1999.44.7.1809

de Madariaga, I. (1992). Interspecific differences in the photosynthetic carbon metabolism of marine phytoplankton. Mar. Biol. 114, 509-515. doi: 10.1007/ BF00350043

Dehairs, F., Kopczynska, E., Nielsen, P., Lancelot, C., Bakker, D. C. E., Koeve, W., et al. (1997). $\delta 13 \mathrm{C}$ of Southern Ocean suspended organic matter during spring and early summer: regional and temporal variability. Deep. Res. Part II Top. Stud. Oceanogr. 144, 129-142. doi: 10.1016/s0967-0645(96)00073-2

Dell'Anno, A., Fabiano, M., Mei, M. L., and Danovaro, R. (2000). Enzymatically hydrolysed protein and carbohydrate pools in deep-sea sediments: estimates of the potentially bioavailable fraction and methodological considerations. Mar. Ecol. Prog. Ser. 196, 15-23. doi: 10.3354/meps196015

Dittmar, T., Fitznar, H. P., and Kattner, G. (2001). Origin and biogeochemical cycling of organic nitrogen in the Eastern Arctic ocean as evident from D- and L-amino acids. Geochim. Cosmochim. Acta 65, 4103-4114. doi: 10.1016/s00167037(01)00688-3

DiTullio, G. R., and Smith, W. O. (1996). Spatial patterns in phytoplankton biomass and pigment distributions in the Ross sea. J. Geophys. Res. C Ocean 101, 18467-18477. doi: 10.1029/96JC00034

DiTullio, G. R., Geesey, M. E., Leventer, A., and Lizotte, M. P. (2011). Algal pigment ratios in the Ross Sea: implications for chemtax analysis of Southern Ocean data. Adv. Earth Spaces Sci. 78, 35-51. doi: 10.1029/078ars03

Duan, S., and Bianchi, T. S. (2007). Particulate and dissolved amino acids in the lower mississippi and Pearl rivers (USA). Mar. Chem. 107, 214-229. doi: 10.1016/j.marchem.2007.07.003

Dubois, M., Gilles, K. A., Hamilton, J. K., Rebers, P. A., and Smith, F. (1956). Colorimetric method for determination of sugars and related substances. Anal. Chem. 28, 350-356. doi: 10.1021/ac60111a017

Ducklow, H. W., Steinberg, D. K., and Buesseler, K. O. (2001). Upper ocean carbon export and the biological pump. Oceanography 14, 50-58. doi: 10.5670/oceanog. 2001.06

Dzierzbicka-Głowacka, L., Kuliński, K., Maciejewska, A., Jakacki, J., and Pempkowiak, J. (2010). Particulate organic carbon in the southern baltic sea: numerical simulations and ttyexperimental data. Oceanologia 52, 621-648. doi: $10.5697 /$ oc. $52-4.621$

Fabiano, M., Povero, P., and Danovaro, R. (1993). Distribution and composition of particulate organic matter in the Ross sea (Antarctica). Polar Biol. 13, 525-533. doi: 10.1007/BF00236394

Fernández-Reiriz, M. J., Perez-Camacho, A., Ferreiro, M. J., Blanco, J., Planas, M., Campos, M. J., et al. (1989). Biomass production and variation in the biochemical profile (total protein, carbohydrates, RNA, lipids and fatty acids) of seven species of marine microalgae. Aquaculture 83, 17-37. doi: 10.1016/ 0044-8486(89)90057-4

Fichez, R. (1991). Composition and fate of organic matter in submarine cave sediments; implications for the biogeochemical cycle of organic carbon. Oceanol. Acta. 14, 369-377.

Finkel, Z. V., Beardall, J., Flynn, K. J., Quigg, A., Rees, T. A. V., and Raven, J. A. (2010). Phytoplankton in a changing world: cell size and elemental stoichiometry. J. Plankton Res. 32, 119-137. doi: 10.1093/plankt/fbp098

Fry, B., and Sherr, E. B. (1989). $813 \mathrm{C}$ measurements as indicators of carbon flow in marine and freshwater ecosystems. Ecol. Stud. 68, 196-229. doi: 10.1007/9781-4612-3498-2_12

Goñi, M. A., Teixeira, M. J., and Perkeya, D. W. (2003). Sources and distribution of organic matter in a river-dominated estuary (Winyah Bay, SC, USA). Estuar. Coast. Shelf Sci. 57, 1023-1048. doi: 10.1016/s0272-7714(03)00008-8 
Gruner, D. S., Smith, J. E., Seabloom, E. W., Sandin, S. A., Ngai, J. T., Hillebrand, H., et al. (2008). A cross-system synthesis of consumer and nutrient resource control on producer biomass. Ecol. Lett. 11, 740-755. doi: 10.1111/j.1461-0248. 2008.01192.x

Guisande, C., Maneiro, I., and Riveiro, I. (1999). Homeostasis in the essential amino acid composition of the marine copepod Euterpina acutifrons. Limnol. Oceanogr. 44, 691-696. doi: 10.4319/lo.1999.44.3.0691

Guisande, C., Maneiro, I., Riveiro, I., Barreiro, A., and Pazos, Y. (2002). Estimation of copepod trophic niche in the field using amino acids and marker pigments. Mar. Ecol. Prog. Ser. 239, 147-156. doi: 10.3354/meps 239147

Guisande, C., Riveiro, I., and Maneiro, I. (2000). Comparisons among the amino acid composition of females, eggs and food to determine the relative importance of food quantity and food quality to copepod reproduction. Mar. Ecol. Prog. Ser. 202, 135-142. doi: 10.3354/meps202135

Gulati, R. D., and Demott, W. R. (1997). The role of food quality for zooplankton: remarks on the state -of-the-art, perspectives and priorities. Freshw. Biol. 38, 753-768. doi: 10.1046/j.1365-2427.1997.00275.x

Haberman, K. L., Ross, R. M., and Quetin, L. B. (2003). Diet of the Antarctic krill (Euphausia superba Dana): II. selective grazing in mixed phytoplankton assemblages. J. Exp. Mar. Bio. Ecol. 283, 97-113. doi: 10.1016/s0022-0981(02) 00467-7

Handa, N. (1970). "Dissolved and particulate carbohydrates,". in Organic Matter in Natural Waters. ed. D. W. Hood. Alaska: Instutional Marine Science, 129-152

Harmelin-Vivien, M., Loizeau, V., Mellon, C., Beker, B., Arlhac, D., Bodiguel, X., et al. (2008). Comparison of $\mathrm{C}$ and $\mathrm{N}$ stable isotope ratios between surface particulate organic matter and microphytoplankton in the Gulf of lions (NW Mediterranean). Cont. Shelf Res. 28, 1911-1919. doi: 10.1016/j.csr.2008.03.002

Harvey, H. R., Tuttle, J. H., and Bell, J. T. (1995). Kinetics of phytoplankton decay during simulated sedimentation: changes in biochemical composition and microbial activity under oxic and anoxic conditions. Geochim. Cosmochim. Acta 59, 3367-3377. doi: 10.1016/0016-7037(95)00217-n

Hayashi, T., Suitani, Y., Murakami, M., Yamaguchi, K., Konosu, S., and Noda, H. (1986). Chemistry and utilization of plankton. VII. protein and amino acid compositions of five species of marine phytoplankton. Nippon Suisan Gakkaishi. 52, 337-343. doi: 10.2331/suisan.52.337

Hecky, R. E., Mopper, K., Kilham, P., and Degens, E. T. (1973). The amino acid and sugar composition of diatom cell-walls. Mar. Biol. 19, 323-331. doi: 10.1007/ BF00348902

Henderson, J. W., Ricker, R. D., Bidlingmeyer, B. A., and Woodward, C. (2000). Rapid, Accurate, Sensitive, and Reproducible HPLC Analysis of Amino Acids. Santa Clara: Agilent Technologies

Hernando, M., Varela, D. E., Malanga, G., Almandoz, G. O., and Schloss, I. R. (2020). Effects of climate-induced changes in temperature and salinity on phytoplankton physiology and stress responses in coastal Antarctica. J. Exp. Mar. Bio. Ecol. 53:151400. doi: 10.1016/j.jembe.2020.151400

Hogle, S. L., Dupont, C. L., Hopkinson, B. M., King, A. L., Buck, K. N., Roe, K. L., et al. (2018). Pervasive iron limitation at subsurface chlorophyll maxima of the California current. Proc. Natl. Acad. Sci. U. S. A. 115, 13300-13305. doi: $10.1073 /$ pnas.1813192115

Hong, Y., Smith, W. O., and White, A. M. (1997). Studies on transparent exopolymer particles (TEP) produced in the ross sea (Antarctica) and by Phaeocystis antarctica (Prymnesiophyceae). J. Phycol. 33, 368-376. doi: 10.1111/ j.0022-3646.1997.00368.x

Hubberten, U., Lara, R. J., and Kattner, G. (1995). Refractory organic compounds in polar waters: relationship between humic substances and amino acids in the Arctic and Antarctic. J. Mar. Res. 53, 137-149. doi: 10.1357/00222409532 13322

Ingalls, A. E., Liu, Z., and Lee, C. (2006). Seasonal trends in the pigment and amino acid compositions of sinking particles in biogenic $\mathrm{CaCO} 3$ and $\mathrm{SiO} 2$ dominated regions of the Pacific sector of the Southern Ocean along $170^{\circ}$ W. Deep. Res. Part I Oceanogr. Res. Pap. 53, 836-859. doi: 10.1016/j.dsr.2006.01.004

Jo, N., Kang, J. J., Park, W. G., Lee, B. R., Yun, M. S., Lee, J. H., et al. (2017). Seasonal variation in the biochemical compositions of phytoplankton and zooplankton communities in the southwestern East/Japan Sea. Deep. Res. Part II Top. Stud. Oceanogr. 143, 82-90. doi: 10.1016/j.dsr2.2016.12.001

Ju, Z. Y., Forster, I., Conquest, L., Dominy, W., Kuo, W. C., and David Horgen, F. (2008). Determination of microbial community structures of shrimp floc cultures by biomarkers and analysis of floc amino acid profiles. Aquac. Res. 39, 118-133. doi: 10.1111/j.1365-2109.2007.01856.x

Kalachova, G. S., Kolmakova, A. A., Gladyshev, M. I., Kravchuk, E. S., and Ivanova, E. A. (2004). Seasonal dynamics of amino acids in two small Siberian reservoirs dominated by prokaryotic and eukaryotic phytoplankton. Aquat. Ecol. 38, 3-15. doi: 10.1023/b:aeco.0000021044.55658.71

Kang, J. J., Lee, J. H., Kim, H. C., Lee, W. C., Lee, D., Jo, N., et al. (2018). Monthly variations of phytoplankton community in geoje-hansan bay of the southern part of Korea based on HPLC pigment analysis. J. Coast. Res. 85, 356-360. doi: 10.2112/SI85-072.1

Kaufman, D. E., Friedrichs, M. A. M., Smith, W. O., Hofmann, E. E., Dinniman, M. S., and Hemmings, J. C. P. (2017). Climate change impacts on southern Ross Sea phytoplankton composition, productivity, and export. J. Geophys. Res. Ocean. 122, 2339-2359. doi: 10.1002/2016JC012514

Kharbush, J. J., Close, H. G., Van Mooy, B. A. S., Arnosti, C., Smittenberg, R. H., Le Moigne, F. A. C., et al. (2020). Particulate organic carbon deconstructed: molecular and chemical composition of particulate organic carbon in the ocean. Front. Mar. Sci. 7:518. doi: 10.3389/fmars.2020.00518

Kim, B. K., Lee, S. H., Ha, S. Y., Jung, J., Kim, T. W., Yang, E. J., et al. (2018). Vertical Distributions of macromolecular composition of particulate organic matter in the water column of the amundsen sea polynya during the summer in 2014 . J. Geophys. Res. Ocean. 123, 1393-1405. doi: 10.1002/2017JC013457

Kirk, J. T. O. (1985). "Effects of suspensoids (turbidity) on penetration of solar radiation in aquatic ecosystems," in Perspectives in Southern Hemisphere Limnology. Developments in Hydrobiology, eds B. R. Davies and R. D. Walmsley (Dordrecht: Springer).

Klausmeier, C. A., Litchman, E., Daufresne, T., and Levin, S. A. (2008). Phytoplankton stoichiometry. Ecol. Res. 23, 479-485.

Kleppel, G. S., Burkart, C. A., and Houchin, L. (1998). Nutrition and the regulation of egg production in the calanoid copepod Acartia tonsa. Limnol. Oceanogr. 43, 1000-1007. doi: 10.4319/lo.1998.43.5.1000

Kolmakova, A. A., and Kolmakov, V. I. (2019). Amino acid composition of green microalgae and diatoms, cyanobacteria, and zooplankton (Review). Inl. Water Biol. 12, 452-461. doi: 10.1134/s1995082919040060

Lamb, A. L., Wilson, G. P., and Leng, M. J. (2006). A review of coastal palaeoclimate and relative sea-level reconstructions using $\delta 13 \mathrm{C}$ and $\mathrm{C} / \mathrm{N}$ ratios in organic material. Earth Sci. Rev. 75, 29-57. doi: 10.1016/j.earscirev.2005.10.003

Lancelot, C., and Mathot, S. (1985). Biochemical fractionation of primary production by phytoplankton in Belgian coastal waters during short- and longterm incubations with 14C-bicarbonate - I. mixed diatom population. Mar. Biol. 86, 219-226. doi: 10.1007/BF00397507

Le Moigne, F. A. C., Boye, M., Masson, A., Corvaisier, R., Grossteffan, E., Guéneugues, A., et al. (2013). Description of the biogeochemical features of the subtropical southeastern Atlantic and the Southern Ocean south of South Africa during the austral summer of the international polar year. Biogeosciences 10, 281-295. doi: 10.5194/bg-10-281-2013

Le Moigne, F. A. C., Cisternas-Novoa, C., Piontek, J., Maßmig, M., and Engel, A. (2017). On the effect of low oxygen concentrations on bacterial degradation of sinking particles. Sci. Rep. 7:16722.

Lee, C., Wakeham, S., and Arnosti, C. (2004). Particulate organic matter in the sea: the composition conundrum. Ambio J. Hum. Environ. 33, 565-575. doi: 10.1579/0044-7447-33.8.565

Lee, S. H., and Whitledge, T. E. (2005). Primary and new production in the deep Canada basin during summer 2002. Polar Biol. 28, 190-197. doi: 10.1007/ s00300-004-0676-3

Lee, S. H., Whitledge, T. E., and Kang, S. H. (2008). Carbon uptake rates of sea ice algae and phytoplankton under different light intensities in a landfast sea ice zone, barrow, Alaska. Arctic 61, 233-346.

Lehmann, M. F., Carstens, D., Deek, A., McCarthy, M., Schubert, C. J., and Zopfi, J. (2020). Amino acid and amino sugar compositional changes during in vitro degradation of algal organic matter indicate rapid bacterial re-synthesis. Geochim. Cosmochim. Acta 283, 67-84. doi: 10.1016/j.gca.2020.05.025

Liebezeit, G., and Bölter, M. (1986). Distribution of particulate amino acids in the Bransfield Strait. Polar Biol. 5, 199-206. doi: 10.1007/BF00446087

Lobbes, M., Kattner, G., and Fitznar, H. P. (1999). Determination of enantiomeric amino acids with high-performance liquid chromatography and pre-column derivatisation with o -phthaldialdehyde and $\mathrm{N}$-isobutyrylcysteine in seawater 
and fossil samples (mollusks). J. Chromatogr. A 832, 123-132. doi: 10.1016/ s0021-9673(98)01000-0

Louropoulou, E., Gledhill, M., Browning, T. J., Desai, D. K., Barraqueta, J. L. M., Tonnard, M., et al. (2019). Regulation of the phytoplankton heme B iron pool during the North Atlantic spring bloom. Front. Microbiol. 10:1566. doi: 10.3389/ fmicb.2019.01566

Lowe, A. T., Galloway, A. W. E., Yeung, J. S., Dethier, M. N., and Duggins, D. O. (2014). Broad sampling and diverse biomarkers allow characterization of nearshore particulate organic matter. Oikos 123, 1341-1354. doi: 10.1111/oik. 01392

Lowry, O. H., Rosebrough, N. J., Farr, A. L., and Randall, R. J. (1951). Protein measurement with the Folin phenol reagent. J. Biol. Chem. 193, 265-275. doi: 10.1016/s0021-9258(19)52451-6

Lyver, P. O. B., MacLeod, C. J., Ballard, G., Karl, B. J., Barton, K. J., Adams, J., et al (2011). Intra-seasonal variation in foraging behavior among Adélie penguins (Pygocelis adeliae) breeding at Cape Hallett, Ross sea, Antarctica. Polar Biol. 34, 49-67. doi: 10.1007/s00300-010-0858-0

Mackey, M. D., Mackey, D. J., Higgins, H. W., and Wright, S. W. (1996). CHEMTAX - A program for estimating class abundances from chemical markers: application to HPLC measurements of phytoplankton. Mar. Ecol. Prog. Ser. 144, 265-283. doi: 10.3354/meps144265

Mague, T. H., Friberg, E., Hughes, D. J., and Morris, I. (1980). Extracellular release of carbon by marine phytoplankton; a physiological approach. Limnol. Oceanogr. 25, 262-279. doi: 10.4319/lo.1980.25.2.0262

Mangoni, O., Saggiomo, M., Bolinesi, F., Castellano, M., Povero, P., Saggiomo, V., et al. (2019). Phaeocystis antarctica unusual summer bloom in stratified antarctic coastal waters (Terra Nova Bay, Ross sea). Mar. Environ. Res. 151:104733. doi: 10.1016/j.marenvres.2019.05.012

Mangoni, O., Saggiomo, V., Bolinesi, F., Margiotta, F., Budillon, G., Cotroneo, Y., et al. (2017). Phytoplankton blooms during austral summer in the Ross sea, Antarctica: driving factors and trophic implications. PLoS One 12:0176033. doi: PMIDNOPMID10.1371/journal.phone.0176033.g005

Marsh, J. B., and Weinstein, D. B. (1966). Simple charring method for determination of lipids. J. Lipid Res. 7, 574-576.

Mathot, S., Smith, W. O., Carlson, C. A., Garrison, D. L., Gowing, M. M., and Vickers, C. L. (2000). Carbon partitioning within phaeocystis antarctica (Prymnesiophyceae) colonies in the ross sea, antarctica. J. Phycol. 36, 1049-1056. doi: 10.1046/j.1529-8817.2000.99078.x

Mayzaud, P., Claustre, H., and Augier, P. (1990). Effect of variable nutrient supply on fatty acid composition of phytoplankton grown in an enclosed experimental ecosystem. Mar. Ecol. Prog. Ser. 60, 123-140. doi: 10.3354/meps060123

Mente, E., Coutteau, P., Houlihan, D., Davidson, I., and Sorgeloos, P. (2002), Protein turnover, amino acid profile and amino acid flux in juvenile shrimp Litopenaeus vannamei: effects of dietary protein source. J. Exp. Biol. 205, $3107-3122$.

Misic, C., Covazzi Harriague, A., Mangoni, O., Aulicino, G., Castagno, P., and Cotroneo, Y. (2017). Effects of physical constraints on the lability of POM during summer in the Ross sea. J. Mar. Syst. 166, 132-143. doi: 10.1016/j. jmarsys.2016.06.012

Moal, J., Martin-Jezequel, V., Harris, R., Samain, J., and Poulet, S. (1987). Interspecific and intraspecific variability of the chemical composition of marine phytoplankton. Oceanol. Acta 10, 339-346.

Montagnes, D. J. S., Berges, J. A., Harrison, P. J., and Taylor, F. J. R. (1994). Estimating carbon, nitrogen, protein, and chlorophyll a from volume in marine phytoplankton. Limnol. Oceanogr. 39, 1044-1060. doi: 10.4319/lo.1994.39.5. 1044

Moore, C. M., Mills, M. M., Arrigo, K. R., Berman-Frank, I., Bopp, L., Boyd, P. W., et al. (2013). Processes and patterns of oceanic nutrient limitation. Nat. Geosci. 6, 701-710. doi: 10.1038/ngeo1765

Morris, I., Glover, H. E., and Yentsch, C. S. (1974). Products of photosynthesis by marine phytoplankton: the effect of environmental factors on the relative rates of protein synthesis. Mar. Biol. 27, 1-9. doi: 10.1007/BF00394754

Muller-Navarra, D. (1995). Evidence that a highly unsaturated fatty acid limits Daphnia growth in nature. Arch. Fur. Hydrobiol. 132, 297-307.

Müller-Navarra, D. C. (2008). Food web paradigms: the biochemical view on trophic interactions. Int. Rev. Hydrobiol. 93, 489-505. doi: 10.1002/iroh. 200711046
Myklestad, S. (1974). Production of carbohydrates by marine planktonic diatoms. I. comparison of nine different species in culture. J. Exp. Mar. Bio. Ecol. 15, 261-274. doi: 10.1016/0022-0981(74)90049-5

Nelson, D. M., DeMaster, D. J., Dunbar, R. B., and Smith, W. O. (1996). Cycling of organic carbon and biogenic silica in the Southern ocean: estimates of watercolumn and sedimentary fluxes on the Ross sea continental shelf. J. Geophys. Res. C Ocean 5, 146-153. doi: 10.1029/96JC01573

Nelson, D. M., Smith, W. O., Muench, R. D., Gordon, L. I., Sullivan, C. W., and Husby, D. M. (1989). Particulate matter and nutrient distributions in the iceedge zone of the Weddell sea: relationship to hydrography during late summer. Deep Sea Res. Part A, Oceanogr. Res. Pap. 36, 191-209. doi: 10.1016/01980149(89)90133-7

Oksanen, L., and Oksanen, T. (2000). The logic and realism of the hypothesis of exploitation ecosystems. Am. Nat. 153, 703-723. doi: 10.1086/303354

Olson, R. J., Sosik, H. M., Chekalyuk, A. M., and Shalapyonok, A. (2000). Effects of iron enrichment on phytoplankton in the Southern Ocean during late summer: active fluorescence and flow cystometric analyses. Deep. Res. Part II Top. Stud. Oceanogr. 47, 3181-3200. doi: 10.1016/s0967-0645(00)00064-3

Oser, B. L. (1959). "An integrated essential amino acid index for predicting the biological value of proteins," in Protein and Amino Acid Nutrition, ed. A. A. Albanese (Amsterdam: Elsevier).

Parsons, T. R., Maita, Y., and Lalli, C. M. (1984). A manual of chemical \& biological methods for seawater analysis. Mar. Pollut. Bull. 15, 419-420.

Peloquin, J. A., and Smith, W. O. (2007). Phytoplankton blooms in the Ross Sea, Antarctica: interannual variability in magnitude, temporal patterns, and composition. J. Geophys. Res. Ocean. 112:C08013. doi: 10.1029/2006JC003816

Peñaflorida, V. D. (1989). An evaluation of indigenous protein sources as potential component in the diet formulation for tiger prawn, Penaeus monodon, using essential amino acid index (EAAI). Aquaculture 83, 319-330. doi: 10.1016/ 0044-8486(89)90043-4

Petersson, M., and Floderus, S. (2001). Use of amino acid composition to investigate settling and resuspension of a spring bloom in the southern Skagerrak. Limnol. Oceanogr. 46, 1111-1120. doi: 10.4319/lo.2001.46.5.1111

Pinkerton, M. H., Bradford-Grieve, J. M., and Hanchet, S. M. (2010). A balanced model of the food web of the Ross sea, Antarctica. CCAMLR Sci. 17, 1-31.

Rau, G. H., Sullivan, C. W., and Gordon, L. I. (1991). $\delta 13 \mathrm{C}$ and $\delta 15 \mathrm{~N}$ variations in Weddell sea particulate organic matter. Mar. Chem. 35, 355-369. doi: 10.1016/ s0304-4203(09)90028-7

Rau, G. H., Takahashi, T., and Des Marais, D. J. (1989). Latitudinal variations in plankton $813 \mathrm{C}$ : implications for $\mathrm{CO} 2$ and productivity in past oceans. Nature 341, 516-518. doi: 10.1038/341516a0

Rickard, G., and Behrens, E. (2016). CMIP5 earth system models with biogeochemistry: a Ross sea assessment. Antarct. Sci. 5, 1-20. doi: 10.1029/ 078ars01

Riley, G. A. (1971). Particulate organic matter in sea water. Adv. Mar. Biol. 8, 1-118. doi: 10.1016/s0065-2881(08)60491-5

Ríos, A. F., Fraga, F., Pérez, F. F., and Figueiras, F. G. (1998). Chemical composition of phytoplankton and particulate organic matter in the Ría de Vigo (NW Spain). Sci. Mar. 62, 257-271.

Rogers, J., and Dunbar, R. (1993). Carbon isotopic composition of particulate organic carbon in Ross sea surface waters during austral summer. Antarct. J. U. S. 28, 81-83.

Sabadel, A. J. M., Van Oostende, N., Ward, B. B. S., Woodward, E. M., Van Hale, R., and Frew, R. D. (2019). Characterization of particulate organic matter cycling during a summer North Atlantic phytoplankton bloom using amino acid C and N stable isotopes. Mar. Chem. 214:103670. doi: 10.1016/j.marchem.2019. 103670

Saito, M. A., Goepfert, T. J., and Ritt, J. T. (2008). Some thoughts on the concept of colimitation: three definitions and the importance of bioavailability. Limnol. Oceanogr. 53, 276-290. doi: 10.4319/lo.2008.53.1.0276

Sarmiento, J. L., Gruber, N., Brzezinski, M. A., and Dunne, J. P. (2004) High-latitude controls of thermocline nutrients and low latitude biological productivity. Nature 427, 56-60. doi: 10.1038/nature02127

Schine, C. M. S., Van Dijken, G., and Arrigo, K. R. (2016). Spatial analysis of trends in primary production and relationship with large-scale climate variability in the Ross sea, Antarctica (1997-2013). J. Geophys. Res. Ocean 121, n/a-n/a. doi: 10.1002/2015JC011014 
Schoemann, V., Becquevort, S., Stefels, J., Rousseau, V., and Lancelot, C. (2005). Phaeocystis blooms in the global ocean and their controlling mechanisms: a review. J. Sea Res. 53, 43-66. doi: 10.1016/j.seares.2004.01.008

Scott, J. M. (1980). Effect of growth rate of the food alga on the growth/ingestion efficiency of a marine herbivore. J. Mar. Biol. Assoc. U. K. 60, 681-702. doi: $10.1017 / \mathrm{s} 0025315400040376$

Sedwick, P. N., and Ditullio, G. R. (1997). Regulation of algal blooms in Antarctic shelf waters by the release of iron from melting sea ice. Geophys. Res. Lett. 24, 2515-2518. doi: 10.1029/97GL02596

Sedwick, P. N., Di Tullio, G. R., and Mackey, D. J. (2000). Iron and manganese in the Ross sea, seasonal iron limitation in Antarctic. J. Geophys. Res. Ocean 102, 11321-11336. doi: 10.1029/2000jc000256

Shields, A. R., and Smith, W. O. (2009). Size-fractionated photosynthesis/irradiance relationships during Phaeocystis antarcticadominated blooms in the Ross sea, Antarctica. J. Plankton Res. 31, 701-712. doi: 10.1093/plankt/fbp022

Shields, M. R., Bianchi, T. S., Osburn, C. L., Kinsey, J. D., Ziervogel, K., Schnetzer, A., et al. (2019). Linking chromophoric organic matter transformation with biomarker indices in a marine phytoplankton growth and degradation experiment. Mar. Chem. 214:103665. doi: 10.1016/j.marchem.2019.103665

Siezen, R. J., and Mague, T. H. (1978). Amino acids in suspended particulate matter from oceanic and coastal waters of the Pacific. Mar. Chem. 6, 215-231. doi: 10.1016/0304-4203(78)90031-2

Smetacek, V., Assmy, P., and Henjes, J. (2004). The role of grazing in structuring Southern Ocean pelagic ecosystems and biogeochemical cycles. Antarct. Sci. 16, 541-558. doi: 10.1017/s0954102004002317

Smith, A. E., and Morris, I. (1980). Pathways of carbon assimilation in phytoplankton from the Antarctic ocean. Limnol. Oceanogr. 85, 865-872. doi: 10.4319/lo.1980.25.5.0865

Smith, W. O., Ainley, D. G., Arrigo, K. R., and Dinniman, M. S. (2014). The oceanography and ecology of the ross sea. Ann. Rev. Mar. Sci. 6, 469-487.

Smith, W. O., and Asper, V. L. (2001). The influence of phytoplankton assemblage composition on biogeochemical characteristics and cycles in the southern Ross sea, Antarctica. Deep. Res. Part I Oceanogr. Res. Pap. 48, 137-161. doi: 10.1016/ s0967-0637(00)00045-5

Smith, W. O., Asper, V., Tozzi, S., Liu, X., and Stammerjohn, S. E. (2011). Surface layer variability in the Ross sea, Antarctica as assessed by in situ fluorescence measurements. Prog. Oceanogr. 88, 28-45. doi: 10.1016/j.pocean.2010.08.002

Smith, W. O., Dennett, M. R., Mathot, S., and Caron, D. A. (2003). The temporal dynamics of the flagellated and colonial stages of Phaeocystis antarctica in the Ross sea. Deep. Res. Part II Top. Stud. Oceanogr. 50, 605-617. doi: 10.1016/ s0967-0645(02)00586-6

Smith, W. O., Marra, J., Hiscock, M. R., and Barber, R. T. (2000). The seasonal cycle of phytoplankton biomass and primary productivity in the Ross sea, Antarctica. Deep. Res. Part II Top. Stud. Oceanogr. 47, 3119-3140. doi: 10.1016/s09670645(00)00061-8

Stammerjohn, S. E., Martinson, D. G., Smith, R. C., Yuan, X., and Rind, D. (2008). Trends in Antarctic annual sea ice retreat and advance and their relation to El Niño-Southern Oscillation and Southern Annular Mode variability. J. Geophys. Res. 113:C03S90. doi: 10.1029/2007jc004269.a

Sterner, R., and Elser, J. (2002). "Ecological stoichiometry," in The Biology of Elements from Molecules to the Biosphere, eds R. W. Sterner, J. J. Elser, and P. M. Vitousek (Princeton, NJ: Princeton University Press).

Sunda, W. G., and Huntaman, S. A. (1997). Interrelated influence of iron, light and cell size on marine phytoplankton growth. Nature 390, 389-392. doi: 10.1038/ 37093

Tang, K. W., Smith, W. O., Elliott, D. T., and Shields, A. R. (2008). Colony size of Phaeocystis antarctica (Prymnesiophyceae) as influenced by zooplankton grazers. J. Phycol. 44, 1372-1378. doi: 10.1111/j.1529-8817.2008.00595.x

Tonon, T., Harvey, D., Larson, T. R., and Graham, I. A. (2002). Long chain polyunsaturated fatty acid production and partitioning to triacylglycerols in four microalgae. Phytochemistry 61, 15-24. doi: 10.1016/s0031-9422(02) 00201-7

Tremblay, L., Caparros, J., Leblanc, K., and Obernosterer, I. (2015). Origin and fate of particulate and dissolved organic matter in a naturally iron-fertilized region of the Southern ocean. Biogeosciences 12, 607-621. doi: 10.5194/bg-12-6072015
Tsukasaki, A., and Tanoue, E. (2010). Chemical characterization and dynamics of particulate combined amino acids in Pacific surface waters. J. Mar. Syst. 79, 173-184. doi: 10.1016/j.jmarsys.2009.08.003

Tyson, R. V. (1995). "The nature of organic matter in sediments," in Sedimentary Organic Matter: Organic Facies and Palynofacies, ed. R. V. Tyson (London: Chaman \& Hall), 7-28.

Vargas, C. A., Escribano, R., and Poulet, S. (2006). Phytoplankton food quality determines time windows for successful zooplankton reproductive pulses. Ecology 87, 2992-2999. doi: 10.1890/0012-9658(2006)87[2992:pfqdtw]2.0.co;2

Villinski, J. C., Dunbar, R. B., and Mucciarone, D. A. (2000). Carbon 13 / Carbon 12 ratios of sedimentary organic matter from the Ross sea, Antarctica?: a record of phytoplankton bloom dynamics the carbon isotopic composition of phytoplankton input from sea ice communities enriched increased heterotrophic these fac. J. Geophys. Res. 105, 14163-14172. doi: 10.1029/1999jc000309

Volkman, J. K., and Tanoue, E. (2002). Chemical and biological studies of particulate organic matter in the ocean. J. Oceanogr. 58, 265-279.

Wada, E., Kadonaga, T., and Matsuo, S. (1975). 15N abundance in nitrogen of naturally occurring substances and global assessment of denitrification from isotopic viewpoint. Geochem. J. 9, 139-148. doi: 10.2343/geochemj.9.139

Wada, E., Terazaki, M., Kabaya, Y., and Nemoto, T. (1987). 15N and 13C abundances in the Antartic ocean with emphasis on the biogeochemical structure of the food web. Deep Sea Res. Part A, Oceanogr. Res. Pap. 34, 829-841. doi: 10.1016/0198-0149(87)90039-2

Wright, S. W., Thomas, D. P., Marchant, H. J., Higgins, H. W., Mackey, M. D., and Mackey, D. J. (1996). Analysis of phytoplankton of the Australian sector of the Southern ocean: comparisons of microscopy and size frequency data with interpretations of pigment HPLC data using the "CHEMTAX" matrix factorisation program. Mar. Ecol. Prog. Ser. 144, 285-298. doi: 10.3354/ meps 144285

Wu, Y., Dittmar, T., Ludwichowski, K. U., Kattner, G., Zhang, J., Zhu, Z. Y., et al. (2007). Tracing suspended organic nitrogen from the Yangtze river catchment into the East China Sea. Mar. Chem. 107, 367-377. doi: 10.1016/j.marchem. 2007.01.022

Young, J. N., Goldman, J. A. L., Kranz, S. A., Tortell, P. D., and Morel, F. M. M. (2015a). Slow carboxylation of Rubisco constrains the rate of carbon fixation during Antarctic phytoplankton blooms. New Phytol. 205, 172-181. doi: 10. 1111/nph.13021

Young, J. W., Hunt, B. P. V., Cook, T. R., Llopiz, J. K., Hazen, E. L., Pethybridge, H. R., et al. (2015b). The trophodynamics of marine top predators: current knowledge, recent advances and challenges. Deep. Res. Part II Top. Stud. Oceanogr. 113, 170-187. doi: 10.1016/j.dsr2.2014.05.015

Yun, M. S., Joo, H. M., Kang, J. J., Park, J. W., Lee, J. H., Kang, S. H., et al. (2019). Potential implications of changing photosynthetic end-products of phytoplankton caused by sea ice conditions in the Northern Chukchi sea. Front. Microbiol. 10:2274. doi: 10.3389/fmicb.2019.02274

Yun, M. S., Lee, D. B., Kim, B. K., Kang, J. J., Lee, J. H., Yang, E. J., et al. (2015). Comparison of phytoplankton macromolecular compositions and zooplankton proximate compositions in the northern Chukchi sea. Deep. Res. Part II Top. Stud. Oceanogr. 120, 82-90. doi: 10.1016/j.dsr2.2014.05.018

Zapata, M., Rodríguez, F., and Garrido, J. L. (2000). Separation of chlorophylls and carotenoids from marine phytoplankton: a new HPLC method using a reversed phase C8 column and pyridine-containing mobile phases. Mar. Ecol. Prog. Ser. 195, 29-45. doi: 10.3354/meps195029

Zweifel, U. L., Norrman, B., and Hagstrom, A. (1993). Consumption of dissolved organic carbon by marine bacteria and demand for inorganic nutrients. Mar. Ecol. Prog. Ser. 101, 23-32. doi: 10.3354/meps101023

Conflict of Interest: The authors declare that the research was conducted in the absence of any commercial or financial relationships that could be construed as a potential conflict of interest.

Copyright $\odot 2021$ Jo, La, Kim, Kim, Kim, Kim, Son and Lee. This is an open-access article distributed under the terms of the Creative Commons Attribution License (CC BY). The use, distribution or reproduction in other forums is permitted, provided the original author(s) and the copyright owner(s) are credited and that the original publication in this journal is cited, in accordance with accepted academic practice. No use, distribution or reproduction is permitted which does not comply with these terms. 